\title{
CAUTIVOS PRECERVANTINOS, CARA Y CRUZ DEL CAUTIVERIO
}

Introducción

E1 cautiverio de Cervantes en Argel (26 septiembre I575-I9 septiembre I580) marcó honda huella en su obra literaria y ha llamado en todo tiempo la atención de beneméritos cervantistas ${ }^{1}$. Los deliciosos libros de Haedo ${ }^{2}$ - deliciosos en sus cuadros llenos de colorido local sobre costumbres y vida de cautiverio argelino-, la crónica o tratado de redención de cautivos de fray Jerónimo Gracián ${ }^{3}$, la memoria

1 Sería interminable citar nombres en el árbol frondoso de la bibliografía cervantina; sirva para nuestro objetivo la valiosa selección de ALBERTo SÁNCHEZ. Cervantes: Bibliografia Fundamental (I900-I959). Cuadernos Bibliográficos, I. Madrid, CSIC, I96r.

2 Fray Diego DE HAEDo, Topographia o descripción de Argel y Diálogos de la captividad, impresos juntamente en I6r2. Edición en 3 tomos de la Sociedad de Bibliófilos Españoles. Madrid, I927-29.

Francisco Rodrf́guez Marín, en su nueva edición crítica del Quijote. Madrid, r948, ilustra el texto con 18 citas del libro de Haedo: II, 388; III, 92, I 75, I 76, I86, I89, I9I, 193, I95, I97, 207, 208, 210, 222, 219; VII, 24I, 243; VIII, IIo. También JAIME: OLIVER Asín recurre numerosas veces a la Topographia de Haedo en su interesante estudio La hija de Agi Morato en la obra de Cervantes. Madrid, I948, vid. pp. I2, I4, I6, I8, 24, 25, 48...

Ia monumental biografía escrita por LuIs ASTRANa MARín, Vida ejemplar y heróica de Miguel de Cevvantes Saavedra. Madrid, I948-1958, 7 vols., contiene un respetable número de citas de la obra de Haedo. Omitimos más referencias que nos llevarían al estudio de Haedo en los cervantistas, que por ahora no nos ocupa.

3 Tratado de la redempción de captivos, obra impresa a continuación de Zelo de la propagación de la Fee. Bruselas, Juan Mommart, MDCIX. RODRÍGUEZ MARín hace referencias a dicha obra relativas al cautiverio norteafricano: Quijote, II, I84; III, I80, r94, I98; VIII, IIO; IX, 20I, omitimos otras referencias por ser puramente gramaticales. 
del cautiverio argelino del mercenario fray Gabriel Gómez de Losada ${ }^{1}$, los procesos inquisitoriales de redención de cautivos del Archivo Histórico Nacional de Toledo ${ }^{2}$, las relaciones verdaderas de fray Jerónimo de Sepúlveda ${ }^{3}$, y ciertos casos extraños sucedidos en Argel ${ }^{4}$, han servido para identificar la "verdad histórica» que sirve de telón de fondo o de cañamazo de la novela del Cautivo inserta en el Quijote ${ }^{5}$ y de la comedia Los Baños de Argel ${ }^{6}$. La crítica e investigación en torno a la obra cervantina no ha regateado esfuerzos llegando a señalar el modelo vivo que pudo inspirar tal o cual personaje literario, como el soldado Alonso López, personaje de carne y hueso, preso en Lepanto y prisionero y galeote del Uchalí ('U $1 \overline{\mathrm{u}} \hat{\mathrm{y}}$ 'A $1 \mathrm{i}$ ), de vida tan semejante, a juicio de Oliver Asín 7, a la del cautivo Ruy Pérez de la magistral novela cervantina.

No menos provechosa ha sido la lectura de la novela del Cautivo y de la comedia Los Baños de Argel, a la luz esclarecedora de las crónicas y documentos ${ }^{8}$ relativos a la historia de Argel y de Marruecos, este contrapunto histórico da mayor relieve y esplendor a los personajes de la obra cervantina situados en el punto de intersección de las coordenadas historia y ficción ${ }^{9}$. Pero, al lado de esos documentos históricos de primer

1 Escuela de trabaios. Madrid, Julián de Paredes, I670. Trata del cautiverio argelino y enumera las crueldades de los turcos, entre ellos las de Azán Bajá, p. 50. Las referencias de RoDRíGUEZ MARín, ed. cit. Quijote son: I, 267; III, 190, 2I2, 219, 289; V, 243, 249; VII, 268.

2 Vid. Quijote, III, 240-I, edición de RoDRf́GUEZ Marín.

3 Relación berdadera de un caso estraño sucedido en Argel imbiado de Roma, año de mill y quinientos $y$ ochenta $y$ siete años. Biblioteca de la Academia de la Historia. Colección de Salazar, F, I7, folios I35-I4I. Extractada por RoDRíGUEZ MARIN, en su ed. Quijote, III, 242.

4 Dicho suceso acaecido en el año 1595 fue recordado por PELIIICER vid. nota 5, p. 242, t. III del Quijote, ed. Rodríguez Marín. También en J. OLIver Asín, La hija de Agi Morato, p. Io.

5 I, cap. XXXIX-XLI; en la ed. cit., tomo III, pp. I67-243.

- Vid. Ocho comedias y ocho entremeses nuevos... en la Edición de la Real Academia Española, facsímil de las primitivas impresiones. Madrid, I917-23. (7 vols.)

7 La hija de Agi Morato, p. 60.

8 Es el camino seguido por J. OIIVER Asf́n en su estudio La hija de Agi Morato que identifica los personajes históricos de Los baños de Avgel, pp. 7-57 y de la leyenda o historia del cautivo del Quijote, pp. 55-ror; Agi Morato es h a $\hat{\mathbf{y}} \cdot \hat{\mathbf{y}}$ i $\mathrm{M}$ u ra $\mathrm{d}$, renegado de padres eslavones; Zahara, hija de Agi Morato, fue educada al cristianismo por un ama llamada Juana de Rentería.

- Vid. notables ejemplos de contacto entre la ficción y la historia en el trabajo de VICENTE ILORf́ns, Historia y ficción en el Quijote. Papeles de son Armadans, 1963, LXXXIV, pp. 233-258. 
orden, hay que colocar otros de asunto al parecer trivial, de la vida cotidiana y -a primera vista - poco transcendente, pero que han captado el constante devenir en el cual los grandes hechos son sólo una excepción. Una cédula de rescate de un cautivo, una minuciosa relación de una cabalgada contra el cabo de Gata, planeada y organizada desde el peñón de Vélez de la Gomera, las declaraciones de un turco escapado de una galeota cerca de Almería, las cartas de justificación de un excautivo, (tal vez esas cartas burlaron la vigilancia del fiero turco, cosidas en unas bolsas y pegadas al cuerpo y a los míseros harapos que lo cubrían ${ }^{1}$ ), la carta de angustia y opresión del cautivo de Vélez de la Gomera (tiene un plazo de dos meses para ser rescatado o vendido en el mercado de esclavos de Fez y pide el envío de cien ducados para su rescate, pero invertidos en tejidos y ropas de buena calidad), las declaraciones de los bardaxas, el episodio de pescadores malagueños que son sorprendidos por los turcos cuando pescaban tranquilamente al palangre, estas y otras relaciones semejantes llenas de vida y de realismo - a veces descarnado realismo-, son las que nos van a ofrecer los viejos papeles de un Archivo ${ }^{2}$, fechados entre I55I-I564, anteriores y próximos al cautiverio cervantino.

Algunos de los documentos, que ahora transcribimos, conservan todavía los dobleces originarios con que se guardaron ocultos en el cuerpo y, tal vez, algo, de la mugre - física y moral - de aquellas almas hundidas en el miserable estado del cautiverio y tan inclinadas a la envidia y a la infamia, al sentir de Vicente Espinel ${ }^{3}$, cuando estaban desprovistas de esa maravillosa fuerza moral de que dio tantas pruebas nuestro inmortal Cervantes. Queremos apartarnos un poco de la ficción literaria y dar paso a la vida misma, aunque ésta sea también ficción o

1 Así lo describe fray JERónImo GRAcián en su Tratado de la redempción de captivos, fol. 48, citado por Rodrf́gueZ MARín, ed. Quijote, III, p. ${ }^{19} 6_{11}$.

2 Archivo de la Alhambra, cuyo fondo documental del siglo xvi estoy estudiando desde el verano de 1960 . Conste mi agradecimiento a D. Jesús Bermúdez Pareja, Director del Museo de la Alhambra y del mencionado Archivo y a la Srta. Dña. Angustias Moreno Olmedo, de la Universidad de Granada, que elabora en dicho Archivo un fichero de materias, cronológico, geográfico... y cuya pericia paleográfica fue paño de lágrimas de tantos investigadores que pasaron por dicho Archivo.

3 Vida de Marcos de Obregón, ed. "Clás. castellános", Madrid, I96o, t. II, p. 69: "y para sosegar la envidia se han de hacer estas diligencias y otras mayores. Que no hay gente que más se gobierne por ella que esclavos, perseguidores de sus iguales, y solapadores de la honra y hacienda de sus dueños. Pocos he visto de los que han pasado por este miserable estado que no tengan algún resabio de infame». 
sueño y sea triste el despertar. Los personajes, salidos de pluma de escribano, tienen todas las angulosidades y aristas de la realidad sensible, no filtrada ni estructurada por la Literatura. Al mismo tiempo esta nuestra incursión por el mundo del cautiverio en el siglo XVI, nos permitirá aprehender un interesante repertorio léxico, sacado de documentos inéditos, con la sorpresa del hallazgo de más de una palabra de primera documentación ${ }^{1}$.

\section{Cara del cautiverio}

Las cédulas de rescate de cautivos, todos presos en Argel, que ahora ofrecemos, representan nuestro contacto con el mundo del cautiverio; consignan el nombre del cautivo, el lugar en que fue cautivado y la jornada o cabalgada en que ocurrió tan triste hecho. Son documentos redactados a instancias de deudos o familiares, esposa, padre, hermano, que, faltos de bienes, piden merced de la renta de los habices de las Alpujarras dedicada al rescate de cautivos y otras obras pías. La cédula otorga la merced y señala la cantidad librada; por lo general, en nuestros documentos, cincuenta ducados, equivalentes a 8.750 maravedís. E1 plazo para gestionar el rescate es de I8o días; el fracaso en la gestión obliga a devolver dicha cantidad al depositario de las rentas de los habices.

Por nuestra galería de cautivos desfilan: Alonso de Quesada, esposo de Juana de la Cruz, vecina de Granada, cautivado hacía seis meses por ciertos corsarios turcos (doc. I); Sebastián de Aguilar, hijo de Gonzalo de Aguilar, vecino de Granada, y preso tres años ha por los turcos (doc. II); Sebastián de Nájara, hermano de Juan López de Nájara, vecino de Granada, y ahora preso en Africa, cautivado en la jornada del conde de Alcaudete, ocurrida en el año I558 (doc. III). E1 mismo documento (III) aclara que el conde de Alcaudete fue capitán general de los reinos de Tremecén y Túnez y alcaide de la ciudad de Orán. Y, por fin, Iñigo Delgado, vecino de Archidona, alférez que fue de la compañía de Hernán Pérez del Pulgar en la mencionada jornada (doc. IV).

Un grupo aparte hemos formado con aquellos cautivos cuya vida está detalladamente - y en lo que respecta al cautiverio- relatada, en probanzas, relaciones de cautiverio, interrogatorios... Así nos encontramos (doc. V) con Juan de Nicolao de Ragusa, que lo tomaron en Mojácar (Almería) como moro y resultó ser cristiano escapado de una

1 Vid. mi Léxico granadino del siglo XVI, RDTP, I962, XVII, pp. I36-192, elaborado también con documentos inéditos del Archivo de la Alhambra. 
galeota de turcos. E1 mundo de la apariencia y el de la realidad andan en juego, como en el mundo novelado de Cervantes; nos viene al recuerdo el capitán turco del capítulo LXIII, parte $2 .^{a}$ del Quijote ${ }^{\mathbf{1}}$ :

-Dime arráez, ¿eres turco de nación, o moro, o renegado?

A lo cual el mozo respondió, en lengua asimesmo castellana:

- $\mathrm{Ni}$ soy turco de nación, ni moro, ni renegado.

-Pues ¿qué eres? - - replicó el Virrey.

- Mujer cristiana - respondió el mancebo.

- ¿Mujer, y cristiana, y en tal traje y en tales pasos? Más es cosa para admirarla que para creerla.

Bajo la apariencia de un arráez turco se nos descubre una donce1la, Ana Félix, morisca y cristiana, que usaba de aquel disfraz para escapar de Africa y del islamismo y unirse a su padre Ricote.

Nuestro Juan Nicolao aparece en "hábito de turco e habla cerrado"; las apariencias, vestido y habla, son bastante comprometedoras, por ello, vienen a continuación comprobaciones de tipo etnológico relacionadas con la costumbre musulmana del cortado o retajado del miembro viril: «miraron si estaba cortado como moro y no se halló cortado". También las apariencias alarmaron al pastor mozo del Quijote ${ }^{2}$ al ver al Renegado y a Zoraida "en hábito de moros». En cuanto al retajamiento en el sentido de 'circuncisión', ya se documenta en el siglo xIv, Castigos de D. Sancho, I6 $64^{3}$ y retajar 'circuncido' en Nebrija; no en vano fueron varios los siglos de tradición islámica y de convivencia cristiano -moro- judía, desde el siglo virr con los cristianos mozárabes sometidos, hasta el xvII con los moriscos sometidos y al fin expulsados. En cuanto a la sumisión de los moriscos, los documentos que ahora estudiamos, muestran cómo era una sumisión más aparente que real, pues en todo momento estaban dispuestos a traicionar al estado español en sus alianzas con los turcos y en su labor de espionaje. Los moriscos, al sentir de Américo Castro ${ }^{4}$, "fueron, sin duda, un peligro político, y estaban en inteligencia con extranjeros enemigos de España, que comenzaba a sentirse débil».

1 p. Io6, t. VIII de la ed. RoDríguez MARín.

2 I, cap. XII, tomo III, pp. 236-7, de la ed. citada: «y como él los vió en hábito de moros, pensó que todos los de la Berbería estaban sobre él, y metiéndose con extraña ligereza por el bosque adelante, comenzó a dar los mayores gritos del mundo, diciendo: - ¡Moros, moros hay en la tierra! ¡Moros, moros! ¡Arma, arma!.»

3 Vid. Corominas, DCELC, IV p. 347 a $55^{-55-52}$.

4 España en su Historia. Cristianos, moros y judios. Buenos Aires, 1948 , p. 54 . 
Y Juan Nicolao, superada la prueba del retajado, puede comenzar a descubrir su verdadera personalidad. Nació en "la Raguza que cae de aquella parte de Venecia»; su lengua es "araguzesa, que es de la Eslabonia»; a los ocho años salió de su tierra y anduvo por la mar en una nave napolitana capitaneada por Marian Sardo, hasta que, yendo de Nápoles, lo cautivaron los moros junto con treinta y ocho hombres de la nave, pues eran siete las galeotas enemigas. Después lo llevaron a Argel y ha estado cinco años cautivo en dicha ciudad y en viajes. $\mathrm{Su}$ amo es Chuce, turco de nación y corsario por las rutas de Argel, Vélez y Tetuán; lleva cinco años en su servicio de dar la menja o comida a la gente; esto explica el no ir aherrojado, pues andaba libre por el barco ocupado en su menester como amenja. Esta palabra y el sobrescrito de unas cartas, escritas por cautivos cristianos, a escondidas de moros y a petición de un compañero de cautiverio de Juan Nicolao: "seu amo querria fazer turquo elle na quis e lle dise que se fese na barqua para dar aviso a V. M. la doma el vro. meu senser e native lugar de escrevir a V. M. uno degno maysque bom ome», con la anotación «E1 sobrescrito de la dicha carta no se entendió ni obo quien declarase la dicha letra", nos hace pensar en esa "mezcla de varias lenguas christianas, y de bocablos que por la mayor parte son italianos y españoles, y algunos portugueses» ${ }^{1}$ que los turcos y moros en Argel llamaban «lingua franca» y que en algún momento se menciona en el Quijote ${ }^{2}$ : "el cual me dijo en lengua que en toda la Berbería, y aun en Constantinopla, se habla entre cautivos y moros, que ni es morisca, ni castellana, ni de otra nación alguna, sino una mezcla de todas las lenguas, con la cual todos nos entendemos». La escena en que beben Sancho, su exconvecino Ricote y los demás pseudoperegrinos y, en el momento culminante de júbilo, acuden a la "lingua franca», imitación del italiano, ha sido certeramente interpretada por Leo Spitzer ${ }^{3}$ dentro del marco del perspectivismo lingüístico en el Quijote.

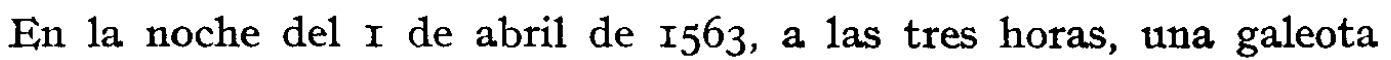
de turcos procedente de Tetuán se acerca a la cala de San Pedro, para tomar agua del pozo de Ocho Ali. Saltan a tierra diez turcos, cinco

I HaIso, Topographia, citado por RodRíguez MARín, ed. Quijote, t. III, p. $2 \mathrm{IO}_{10}{ }^{\circ}$.

2 Quijote, I, cap. XI, ed. Rodrf́guez MARín, t. III, p. $2 \mathrm{IO}_{\text {6-10. }}$.

3 Vid. e̊l estudio Perspectivismo lingüistico en el Quijote, pp. I6I-225 de su libro Lingüistica e Historia Literaria. Madrid, 1955, y especialmente p. I86, nota 19. 
mudéjares ${ }^{1}$ y el declarante Juan Nicolao. Es el mejor momento para dejar el barril entre unas cañas y huir a la montaña y la ocasión es bien aprovechada. Una noche de continuo caminar, ocultándose por los secos y espinosos matojos de las ramblas, evitando el encuentro con los turcos, saboreando su primer amanecer como hombre libre y siempre huyendo, hacia adentro. Ha llegado a la rambla de Macenas, encima del Garrobo, junto al camino de la mar; es ya mediodía cuando divisa, a lo lejos, dos hombres que no tienen apariencia de turcos; son Francisco de Almaraz y Juan Ridao el Saludador, que se hacen cargo de aquel mancebo en hábito de turco y habla cerrada, y lo presentan a la autoridad de Mojácar para que se les adjudique.

A lo largo del interrogatorio vamos conociendo que el mencionado bajel salió de Tetuán diez o doce días antes, que fue derecho a $1 a$ costa de Málaga, donde apresó a tres cristianos, y unia barca, que estaban pescando al palangre - notemos la fecha $\mathrm{I}_{5} 63$ en que se registra la palabra, frente a la fecha 1793 que registra Corominas" como primera documentación en lengua castellana-; los pescadores se dejaron engañar por las apariencias, por el mundo de ficción, al tomar por navío de cristianos aquel bajel pequeño de catorce bancos que llevaba vela pequeña.

Después de cuatro o cinco días de navegación, y llevados por un viento favorable, vinieron a parar al cabo de Gata, y de allí, por las calas adeiante, a la cala de San Pedro. En el cabo de Rodalquilar cin(c) moriscos, que habían salido por almagra, armados de bailestas y arcabuz, siembran cl espanto en los turcos desembarcados, pues creen que eran soldados; al fin, moriscos y turcos entran en contacto y, al saber el intento turco de saitear y robar la costa, dan toda clase de información y facilidades.

Ahora Juan Nicolao da noticias sobre el cerco de Orán por los moros, por tierra y por mar, cercada por unos cincuenta navios ${ }^{3}$. Ein Tetuán sólo quedaban cuatro bajeles sin armar.

Fin un segundo interrogatorio el cautivo es sometido a una prueba, frecuente en la época, para descubrir si era cristiano o no: «y le

1 LEO SPITZIR, op. cit. p. I93 señala las frecuentes excursiones de Cervantes a lo que llamariamos hoy "geografía dialectal" y entre ellas cita el pasaje del Quijote, I, cap. XII, t. III, p. 208: "Tagarinos llaman en Berbería a los moros de Aragón, y a los de Granada, mudéjaves; y en el reino de Fez llaman a los mudéjares elches".

2 DCELC, III, p. $622 \mathrm{~b}_{6}$.

3 Tuvo lugar el año I563; vid., mús abajo Aspecto histórico. 
mandó...... que se santigue e diga la dotrina xristiana». Dice el avemaría y el paternoster en latín y se empieza a santiguar, aunque no bien; en cuanto al credo y a la salverregina, sólo recuerda el comienzo en lengua "araguzesa», que lo cautivaron de chico.

A la pregunta de si ha servido de bardaxa, cuando chiquito, niega con hondo fervor tal imputación, pues su amo tenía para tal menester dos garzones, uno de Gibraltar y el otro llamado "el español».

Como es sabido bardaxa 'sodomita paciente' se documenta en ${ }_{5} 526$ y Siglo de Oro, bardax hacia I60o y bardaje en el siglo xvIr. La presencia de esta palabra en el árabe bardaŷ 'esclavo', en el persa bardah 'caiutivo esclavo', cat. bardaix, it. bardassa, bardascia 'muchacho' y dialectos italianos, lomb., piam., servigliano, sardo (Vid. Corominas, $D C E L C, \mathrm{I}, 402)$, nos hace pensar en una palabra de uso corriente en el Mediterráneo y en una desviación sexual muy frecuente en los corsarios turcos cuando se menciona en las obras de Haedo ${ }^{1}$, de fray Jerónimo Cracián ${ }^{2}$ y de fray Antonio de Gouvea ${ }^{3}$, obispo de Cirene. Ahora, a la agria luz de los documentos, se comprende el pasaje del cap. I,XIII de la 2. ${ }^{\text {a }}$ parte del Quijote y nos escandalizan menos que a Clemencín y Pellicer las siguientes palabras puestas en boca de una doncella de veinte años: "Turbéme, considerando el peligro que don Gregorio corría, porque entre aquellos bárbaros turcos en más se tiene y estima un mochacho o mancebo hermoso que una mujer, por bellísima que sea....... contéle el peligro que corría el mostrar ser hombre, vestíle de mora..."

$\mathrm{Y}$ continúa el interrogatorio de Juan Nicolao. Ahoran salen a relucir las cartas de recomendación escritas por los compañeros durante el cautiverio; firman Bartolomé de Baeza, Gabriel de Espinosa, Juan de Alcántara y Miguel de Limán. E1 Tratado de la redempción de cautivos

1 En su Topographia, en un pasaje citado por RODRfGuez Marín en su ed. Quijote, t. VIII, p. IIо .

2 Tratado de la redempción de captivos, fol. 6v: "De los muchachos y moços desbarbados por maravilla se escapa alguno; porque, aunque sea un grumete, o el más baxo y pobre, le compran los Turcos con excessivo precio, para sus maldades... Iuego en comprándole le visten ricamente, y le regalan con comidas y halagos, persuadiéndole se vuelva turcon, apud RoDríguez Marín, ed. Quijote, VIII, p. r ro.

3 En la dedicatoria del Sermón exhortatorio que... predicó a los esclavos de Argel. Mallorca, Manuel Rodríguez y Iuan Piza. MDCXX: «Ultra destos de los cautivos - me traen cuydadoso muchas donzellas y muchachos de tierna edad, cuya fe y honestidad es perseguida y impugnada con ruegos, con promesas y dadiuas, con amenazas y tormentos cit. por RoDRígurZ MARÍ, ed. Quijote, t. VIII, p. IIo. 
de Gracián ${ }^{1}$ y el cap. XL de la r. a parte del Quijote están de acuerdo, en este sentido, con nuestros documentos:

doc. I, f. $5 \mathrm{v}$ :

como él tenía voluntad de huirse e venirse a tierra de xristianos, les rogó que les hiziesen las dichas cartas, para que se paresciese la verdad y no lo estorbase nadie, e que las dichas cartas las escribieron los dichos cativos xristianos, a escondidas de los moros, porque, si los vieran los moros escrivir las dichas cartas, los mataran a palos.

$$
\text { Quijote, I, cap. XI: }
$$

Pues uno de los renegados que he dicho era este mi amigo, el cual tenía firmas de todos nuestros camaradas, donde la acreditábamos cuanto era posible; $y$ si los moros le hallaran estos papeles, le quemaran vivo.

Ahora el cautivo debe ser enviado a Granada para que el conde de Tendilla, Capitán General del reino de Granada, abra información sobre noticias de interés nacional, como era todo lo referente al cerco de Orán. También era obligatoria la presentación al Tribunal del Santo Oficio, para que «en lo que toca a su ánima, se provea lo que más convenga». Antes de marchar a Granada, el cautivo solicita pública información de los testigos presenciales de su llegada, y hasta aparece un excautivo de Vera, Gaspar Vázquez, en otro tiempo galeote en una galera de Argel, que había visto, hacía año y medio, al dicho Juan Nicolao herrado en la cadena al remo.

Ya en Granada, el procesado $\mathrm{s}^{\mathrm{e}}$ dirige al conde de Tendilla y, haciendo resumen de su cautiverio y huida disimulada entre turcos y monfies, refiere el encuentro en Mojácar con dos guardas y ahora pide la libertad, por estar preso sin culpa y por ser cristiano. Notemos la palabra monfies, registrada en el documento del año 1563 y que Corominas, DCELC, III, 422, documenta por primera vez en 1580 , Hurtado de Mendoza.

Por fin, revisado el proceso y después de un tiempo prudencial dentro de los trámites legales, es puesto en libertad el I7 de mayo del

1 Tratado de la redempción de captivos, fol. 48: "venían a mí muchos renegados que les diera cartas para la inquisición, testificando que se yuan de su voluntad a tierra de Christianos (que por el temor della dexan muchos de venir). Dauales estas certificaciones, cosiéndolas dentro de unas bolsas que ellos trahen con nóminas de Mahoma, con las quales se huyeron a tierra de Christianos algunos; mas si cogieran los Turcos algunas destas cédulas, al que toparan con ellas y a mí nos quemaran." 
año $\mathrm{r}_{563}$ y se le extiende un escrito o credencial que dé fe de cómo fue «preso e suelto" por mandato de la superioridad por ser cristiano y no ser hombre de mal vivir. El I9 de mayo se autoriza la redacción de de dicho credencial. Después de este desenlace feliz, consignado en los documentos, sólo la imaginación puede relatar el regreso de Juan $\mathrm{Ni}$ colao a su Ragusa natal, enrolado en otra nave napolitana, y el reencuentro con su antiguo patrón Marian Sardo, también cautivado por los turcos y ahora también libre tras un sinfín de aventuras. Pocos datos hay que añadir a los consignados en estos documentos fidedignos para que se nos descubra la trama y la urdimbre de una verdadera novela de cautivo, y se evidencie mejor la acertada selección que Cervantes hizo de todo este mundo real para componer sus páginas eternas, mezcla de realidad y ficción.

Pero no siempre estas novelas de cautiverio tenían tan dichoso y aventurado desenlace; lo más frecuente es descubrir en los documentos todas las lacras y miserias, torturas y vilezas de las almas encadenadas física y moralmente.

\section{Cruz del cautiverio}

Ese otro aspecto de miseria moral es el que nos va a presentar la galería de cautivos que a continuación ofrecemos.

E1 documento VI es una triste y desgraciada novela de cautiverio; su protagonista es Juan Andrés, napolitano, mancebo en hábito de turco, con un mechón ${ }^{1}$ de cabellos en la cabeza y lo demás rapado, sin barba, apresado por el guarda de la estancia de la Guardia Vieja, de la ciudad de Mojácar, en la rambla de las Tueras, el 22 de septiembre de ${ }_{563}$.

Declara dicho mancebo haber nacido en Nápoles y llamarse Juan Andrés, aunque en turquesco le llamaban Alí. Sólo se acuerda del paternoster y del avemaría. Habla castellano claro; venía de la Mesa de Roldán y de la Carbonera, de seis galeotas de turcos de que escapó a nado; llevaba tres años en poder de moros y lo tomaron en Nápoles, yendo de esta ciudad en una saetía ${ }^{2}$, con un cargamento de vino. Las galeotas de turcos hacían la ruta de Argel a Vélez de la Gomera y ocho días antes salieron de esta plaza con el alcaide de Vélez y tomaron la

1 Corominas, DCELC, III, p. 3I $7 \mathrm{~b}_{42}$, señala mechón en CÉsar Oudin, Tesoro de las dos lenguas francesa y española. París, r. a ed. 1607 ; nuestros documentos del año $\mathrm{r}_{5} 63$ (doc. VI, f. $1 \mathrm{r}_{10}$ ) escriben siempre menchón.

2 La saetía 'cierto tipo de embarcaeión latina' se documenta ya en las Partidas (II, xxiv, ed. Acad. II, p. 264). Vid. Cokomas, DCELC, IV, p. i i6-7. 
vía de Ceuta para hacer los robos y piratería en las costas españolas. Ya en la playa de Mojácar (Almeria), apresaron cinco barcas de pescar.

Toda la miseria y cruz del cautiverio se nos revela en la confesión de este muchacho obligado a servir de "bardaxa e garcón» a su amo Nabí: "Preguntado que, pues dize que es xristiano, que cómo lo dexaban los moros andar suelto por las galeotas y en ábito de moro. Dixo que como lo tomaron mochacho, se echaron con él y servía de bardaxa e garçón, e que se echaba con él Nabí, su amo. Y este confesante era su garçón, e por esto lo llevan suelto. E que siempre a tenido miedo este qonfesante de los moros e por esto no se a huido hasta agora que tubo logar».

Todo el miedo y el horror a la bestialidad de aquellos perversos, sıfrida por el muchacho desde muy pequeño, explica su huida, su persistencia en la santa fe católica. En efecto se comprueba que los moros "no le cortaron a este qonfesante el capillo del mienbro" y "el dicho señor alcalde lo miró e hizo mirar y no se halló cortado». Luego se aclara que el mechón de cabellos largo en la cabeza rapada era costumbre y distintivo de bardaxas.

A lo largo del interrogatorio se nos descubre toda una traina novelesca de piratería y espionaje, así como la complicidad de tres mudexares y dos moriscos que saltan a tierra a "tomar lengua" y espiar, ei el cabo de Gata y después vuelven "con lengua" a embarcarse en la Mesa de Roldán.

Iras noticias que el muchacho nos da de sus progenitores podrían muy bien servir de comienzo a una novela picaresca: su padre era calabrés; su madre, napolitana; murieron en Nápoles de una "pestilencia»; luego rectifica y dice que su padre murió en la cárcel de Nápoles en un tormento, por muerte de un hombre, y que no se acuerda más de lo que le decía de ellos su tío Marco de Riza, vecino de Nápoles y escribano.

E1 hecho de haber sido "bardaxa e garçón de los moros», el llamarse Alí, nombre de moros, y el ser portador de la noticia de que "xristianos nuebos de este reino de Granada an entrado y salido en los dichos nabios moros» hace precisa - y así lo manifiesta Alonso Hernández, requeridor de Mojácar, como familiar del Santo Oficio- la remisión del cautivo a la ciudad de Granada para "reducirse por medio de la Santa Inquisición al gremio Santísimo de la Iglesia” como dijo Cervantes a propósito de su Renegado (Quijote, I, cap. XLI, p. 240).

Hemos de suponer que Juan Andrés, bardaxa forzado y no retajado, pudo en Granada dar pruebas de su inocencia y de su fervor religioso $\mathrm{y}$, después de cumplida alguna penitencia, fuera admitido de nuevo en el seno del catolicismo. Los procesos seguidos por la Inquisición 
de Toledo, que se conservan en el Archivo Histórico Nacional, relatan con precisión estos pormenores, según noticias de $\mathrm{F}$. Rodríguez Marín en su edición del Quijote (t. III, pp. 240-I, nota I3).

Finalmente, en esta galería de cautivos, nos topamos con el negro Mazote (doc. VII) tomado en el río de Almería, después de ciertas andanzas por Tabernas, en misión de espionaje; Mazote habla siciliano y turco y su imaginación es fértil en leyendas y mentiras; por ello andaba variando en la confesión que le tomaron para saber si era moro, turco o cristiano; por ello fue llevado a la cárcel pública de Almería y puesto en el potro de tormento, con las cuerdas y garrotes en pies y brazos, y sometido a interrogatorio. Había noticia de unas galeotas de turcos, que estaban en el cabo de Gata, y era de gran interés saber si huyó de ellas o de otras.

Por lengua del capitán Pedro de Samaniego se le hace saber que está obligado a decir la verdad, pues si algún brazo o miembro se le quebrare sería a su cargo.

Al primer jarro de agua fría, esto ocurría el 23 de enero de $155 \mathrm{I}$, declara que es moro; terminada de echar el agua, vuelve a decir que es moro, que se llama Maçote y que vino en ocho galeotas de turcos que estaban en el cabo de Gata; el capitán es Mahomet y vinieron de los Gelbes.

Y Maçote continúa su confesión... Había sido retajado en Trípolis, y bautizado en Mesina; que a los ocho años fue hurtado por un moro y vendido como esclavo. Antes había declarado que se llamaba Xristóbal y ahora rectifica y dice que dicho nombre lo había dicho porque así se lo había aconsejado un morisco de Tabernas.

Desde este momento la confesión es vacilante, incierta, y se ven precisados a echarle un jarro de agua y apretarle los cordeles con los garrotes. Ahora confiesa que el amo que tuvo en Sevilla se llama Antonio Mercadante; que su nave pasó por estas partes de la mar; que de allí pasó a Granada y conoció a Aguado y a Escobar, vecinos de dicha ciudad, y que Aguado es bajo de cuerpo raheiz ${ }^{1}$. En Granada dice haberse acogido en casa de un cristiano nuevo llamado Alonso Zaharo, que vive una legua fuera de Granada; luego rectifica y dice que se acogía en casa de Antonio, que vive en la Plaza Nueva.

Estas variaciones motivan que sea castigado con tres jarros sucesivos de agua fría. Entonces dice la verdad: que es moro y que escapó de las ocho galeotas, porque lo maltrataban. Todo lo que antes había

1 Del ár. rajîṣ 'barato', esp. rehez 'barato', 'vil, bajo'. 
contado de ser de Sevilla y esclavo de Antonio Mercadante se lo había sugerido un morisco, junto a Tabernas. Estuvo cuatro días en el campo, cerca de Tabernas, con dos moriscos. De las galeotas había sacado una chamarra colorada, un arco y un alfanje. Los dos moriscos guardaban ganado cabrio, y los reconocería si los viera.

Después los documentos nos trasladan a la villa de Tabernas, para tomar declaración a los pastores Alonso Chodón, Alonso el Modaguar y Martín el Modaguar, sobre los cuales recaen sospechas graves de encubrimiento y convivencia con el turco Mazote, a quien aleccionaron en toda suerte de patrañas para pasar desapercibido. La confesión de estos pastores es poco clara y convincente y se ordena el traslado de los mismosi a la ciudad de Almeria.

Aqui terminan los documentos; la realidad es fácil de imaginar: el turco Mazote tal vez bajara a hacer lengua y a espiar la tierra de cristianos para llevar noticia a las galeotas y preparar el ataque $\mathrm{y}$ asalto de los caseríos; todo ello con la complicidad de los moriscos, que, en este caso, fue descubierta. También es probable que los malos tratos que daban al negro Mazote le impulsaran a la huida y a la liberación de su vida de cautiverio con sus correligionarios. En tal caso, nos hallamos con un hombre que quiere borrar su pasado $\mathrm{y}$ vivir una nueva vida, con personalidad distinta, como esclavo sevillano de un Juan de Marcadante, que tal vez sólo existió en la imaginación de sus asesores moriscos de Tabernas.

La cabalgada del alcaide de Vélez de la Gomera contada por un cautivo

Ya hemos oido la declaración del cautivo Juan Andrés, napolitano, que venía en las seis galeotas que mandaba el alcaide de Vélez y que pudo escapar a nado. Ahora vamos a descubrir cómo se preparaban las cabalgadas contra las costas españolas, desde Vélez de la Gomera, y cómo los moriscos acudían a esta plaza turca para informar los sitios y lugares menos vigilados de la costa que podían ser sorprendidos y sometidos a pillaje. También se descubre el trato que los turcos solían dar a los moriscos que, confiados, esperaban encontrar la libertad y sólo hallaban ultrajes y vejaciones.

Todo esto está contenido en la declaración del excautivo Juan Lorenzo (doc. IX), vecino de Gibraltar, hijo de Juan Lorenzo y de María Rodríguez Burda. Estuvo cautivo en los ocho navios con que el alcaide de Vélez llevó la cabalgada de Nixar y Torval y la expedición se organizó de la siguiente forma: partieron de Argel seis navíos y fueron la 
vuelta de Vélez y, estando en Vélez, un morisco que decía ser de este reino de Granada, y que se dice Haçán, le dijo al alcaide que había un casar en el cabo de Gata dispuesto para irse con los turcos y que la ocasión era propicia.

No esperó más el de los Vélez, que zarpó con seis navíos y, a la vuelta del cabo de Gata, más acá de la Mesa de Roldán, en el pozo que dicen Chavali, desembarcó el dicho Haçán y dos moriscos que se habían pasado de Níjar. Al día siguiente vuelven los moriscos y avisan que no era tiempo de cabalgada, que la costa estaba segura y la gente avisada. Partieron los dos moriscos y los restantes se reintegraron a sus naves. La flota pone proa a Cartajena y Alicante y en Isla Grosa se le juntaron otros dos navíos, después de haber apresado dos naos. De allí todos marchan a Vélez, donde dejan a buen recaudo las dos naos apresadas, vuelven a Vera, donde apresan cinco barcas, se llevan cuatro y dejan una. Se dirigen al puerto más acá de la Mesa de Roldán, donde arribaron con siete galeotas y cuatro barcas, ya que una galeota quedó vigilante en la sierra del cabo de Gata. Poco después se reunían en el puerto las ocho galeotas y desembarcaban Haçán y los otros dos espías moriscos. A1 dia siguiente regresaban con el informe de que ya era tiempo de echar la gente a tierra, pues los vecinos del casar estaban prestos para la fuga y además no había gente de guerra.

El desembarco se hace un poco al poniente de la Torre de los Alumbres, en una caleta, en la sierra, en un cerro alto. Pisan tierra ocho banderas con hasta seiscientos hombres de guerra, bien armados de esčopetas, arcos y ballestas; ocho o diez hombres quedan abajo, de guardia, vigilando a los cautivos, que estaban muy aherrojados.

Toda la gente estuvo en tierra hasta que anocheció, con las banderas tendidas y un morabito predicándoles; en ese momento empezaron a internarse en tierra. Ya oscurecido, cuatro navios fueron sobre los lances de los pescadores, en el cabo de Gata, y los otros cuatro quedaron frente a la sierra, hasta que un fuerte levante obligó a los cuatro, "forcejando con el dicho levante», a juntarse con los demás, más al poniente, donde desembarcaron. A1 día siguiente, por la tarde, se juntaron con las otras cuatro galeotas que habían reembarcado la gente de guerra y que ahora se repartió por sus respectivos navíos. E1 alcaide de Vélez, en charla con la gente de su navío, se informa del resultado de la expedición por tierra. Habían encontrado gente de a caballo y de a pie; habían faltado cuatro turcos; de tres no se supo de ellos, y a uno lo mataron, que era guardián del dicho alcaide. En este encuentro y lucha con la gente de guerra apresaron cuatro cristianos, que llevaban cautivos. Juan Lorenzo los vio y cambió con ellos impresiones, decían 
que eran soldados los tres y el otro era un viejo, alto de cuerpo, que se llamaba Santa Cruz.

Hay un momento de gran expectación entre los cautivos de las galeotas cuando echan al remo a los cuatro cristianos recién apresados; era el contacto con el mundo libre tan añorado, eran noticias de la esposa, madre, padre, hermanos, pueblo, las que podian portar aquellos nuevos compañeros de infortunio. Las circunstancias en que fueron apresartos no se dejan de relatar. Los cuatro soldados habían venido con algunos de a caballo y habían sido puestos a la escucha; uno, estando tras una mata, vio venir un turco, echó a huir y fue apresado; también a los otros dos compañeros; el cuarto. como tenía buenos pies, pudo escapar.

Eistando los navios juntos, transcurrió aquel día y el siguiente, y echaron suertes $y$ "dixoles bien el libro» para que echasen la gente en tierra. Siguieron a levante, media lengua o algo más, porque era cerca de la torre, en las calas, a la parte de levante. Juntas las naves en una cala, echaron la gente a tierra, con media hora de sol; iban con sus banderas; en los navíos quedó la guardia acostumbrada.

Todos marcharon rambla arriba, en dirección a un cerro alto. Al día siguiente tornaron a las naves con gente del casar, ganado y bestias. Los hombres del casar llevaban ballestas, también los mancebos. Mataron mucho ganado para que todos comieran y, después de un pequeño descanso, embarcaron todos, y con ellos siete acénilas muy buenas que se las adjudicaron al alcaide.

Los hombres iban de buena gana, pero las mujeres y niños y muchachos "algunos iban llorando e de mala gana», aunque después se contentaron con las buenas palabras y promesas del alcaide de Vélez. Al día siguiente pasaban por la playa de Almería y tocaron en las Roquetas y estuvieron allí todo el día con una bandera tendira en la capitana y mataron el ganado y salaron con la sal de las Roquetas. Esperaron todo el día por si venía alguien a rescatar alguno de los cautivos: un tal Jiménez, vecino de Almería, y la guardia y soldados. Aquella misma noche pusieron rumbo a Vélez.

Llegaron felizmente a Vélez con el feliz término de la cabalgarla $y$, al cabo de quince dias, rescataron al cautivo declarante, Juan Lorenzo, por ciento sesenta ducados. Tenía entendido del alcaide de Vélez y de la gente de guerra que los turcos tenían propósito de volver pronto al cabo de Gata a secuestrar otro casar y probablemente sería pasado el mes de enero, en la luna de febrero, porque el citado alcaide sólo esperaba dos navíos de Argel, que tenía un renegado suyo, y el cobro de unos dineros de unos portugueses. Unos moros de la sierra de los 
Alerzes estaban dispuestos al alzamiento; convenía pues atajar presto estas maniobras.

La suerte de los moros del casar que se fueron con los turcos con sus mujeres, niños, armas, ropa y bestias fue muy variada, y nada feliz. Cada uno de los hombres, mujeres y niños pagaba diez ducados, y el que no los pagaba, lo echaban al remo o lo tenían encadenado en la fortaleza de Vélez. A los que se quejaban de la nueva "libertad», los echaban al remo. El testigo dice haber visto meter al remo a cinco de los moriscos pasados allende, y a uno lo echaron al remo en su banco, y fue compañero de fatigas en el bogar.

La última pregunta está formulada con un especial interés por comprobar el funcionamiento del sistema defensivo de las costas del reino de Granada y del fiel cumplimiento de su reglamento por la gente de guerra afecta a este servicio ¿Durante el tiempo que estuvieron en la sierra de Gata vieron guardas o hicieron algunas ahumadas en tierra? Era lo obligado, pues era un día claro y estaban descubiertos y públicos en las calas. Recordemos que Espinel, Obregón II, p. 50, trae la noticia de que quince hachas, encendidas en la costa de Mallorca, avisail la presencia de quince galeotas de Argel. Y hasta el mismo Espine1, Obregón II, p. 48, pregona la fama del hachero o atalaya de Gibraltar, de tan increíble y perspicaz vista, que veía desde el Peñón las galeotas que se armaban en Africa.

Pero la respuesta del excautivo Juan Lorenzo, vecino de Gibraltar y tal vez conocedor de las virtudes del atalaya de su pueblo, refleja toda la indignación que merece la falta de vigilancia en las costas, pues no vieron guardas, ni ahumadas, de día ni de noche, y los piratas pudieron actuar con entera confianza "como lo podían estar las galeras de España». Durante el día andabail sueltos y desemboscados, a su antojo, $\mathrm{y}$ de noche estaban surtos en las calas, con sus lumbres y «lanternas en cruxía), sin recelo ni miedo.

E1 excautivo Juan Lorenzo era de 22 años de edad y estuvo cautivo dos años y medio del alcaide de Vélez. Iba bien ataviado con capa y sayo negro, con "saragueles» azules de buen paño y zapatos y gorra. Dijo ser marinero en un barco, de Gibraltar, de un deudo suyo que vino a la ciudad de Almería.

No siempre los moriscos o cristianos nuevos actuaron como cómplices y organizadores de los ataques a las costas españolas por los piratas turcos, no siempre actuaron como traidores en este mundo de cautiverio que los documentos nos va perfilando; prueba de ello son los traslados de dos cédulas y provisiones de don Juan de Austria, que 
incluimos en nuestro documental (docs. XI y XII), fechadas ambas en noviembre de 1570 , por las que, no obstante el decreto de expulsión, autoriza a vivir en la ciudad de Granada a dos cristianos nuevos por su lealtad y fidelidad al servicio del rey.

\section{Aspecto histórico}

I,os documentos de cautivos que ahora publicamos y muchos más, que por ahora quedan inéditos y que merecerían una detallada revisión y estudio, contienen un verdadero arsenal de noticias sobre la vida marinera y costera del Mediterráneo en el siglo xvi y sobre el sistema de defensa de las costas y táctica de ataque de los turcos. Así el doc. I, f. $2 \mathrm{~V}$ trae noticias sobre el cerco de Orán en I563 por cincuenta navíos turcos. Como es sabido, el na'ifragio, en I562, de don Juan de Mendoza en el puerto de la Herradura, cuando iba a aprovisionar la plaza de Orán, animó a Hazen Baxá, rey de Argel, a poner estrecho cerco a la citada plaza, dada su falta de reservas. (Vid. Cabrera de Córdoba, Felipe II, Rey de España. Madrid, ı876, p. 36r.) 'lambién es sabida la defensa que de dicha plaza de Orán hizo el gobernador de la misma, conde de Alcaudete, defensa heroica y desespera $1 \mathrm{la}$, mientras esperaba el socorro de España. Precisamente el doc. III es la cédula de rescate de Sebastián de Nájara, vecino de Granada y ahora preso en Africa, cautivado en la jornada del conde de Alcaudete. El doc. III citado aclara que el conde de Alcaudete fue Capitán General de los reinos de 'Tremecén y Túnez y alcaide de la ciudad de Orán. İ1 documento IV es la cédula de rescate de otro cautivo en la memorable jornada, Iñigo Delgado, vecino de Archidona, alférez que fue de la compañía de Hernán Pérez del Pulgar. 'Gracias al talento militar del conde de Alcaudete se salvó la plaza, en u1la de las más heroicas defensas de la época, dando tiempo a que llegase el auxilio impetrado a Felipe II, que dio vista a la plaza sitiada el 8 de junio ${ }^{1}$.

Gracias a nuestros documentos vemos las rutas marineras de ArgelVélez-Tetuán (doc. I, 4r) recorridas por la piratería turca, Sabida es la dificultad de avituallamiento que presentaba el Peñón de Vélez de la Gomera, ocupado por la escuadra a las órdenes de Pedro Navarro en I508, y abandonado por dicha dificultad en I522. Al regreso del socorro de Orán, la armada recibió orden de Felipe II de atacar por sorpresa el Peñón, en Málaga; por indisposición de Francisco de Mendoza, se hizo cargo del mando don Sancho de Leyva (junio I563). Ell alcalde de Melilla, Pedro Venegas, era el autor del plan de ataque y se contaba con las ofertas de dos renegados. La falta de artillería para 
batir el Peñón obligó al de Leyva a levantar el campo y a reembarcar su ejército. No cejó Felipe II en su intento de eliminar el peligro que representaba el Peñón en manos de los moros y mandó reunir una gran flota de galeras al mando de don García de Toledo, marqués de Villafranca. En agosto de $5_{564}$ se juntaron en Málaga 93 galeras y unos 60 navíos con 13.000 hombres; el 29 de agosto se hizo la flota al mar. El 3 de septiembre, después del desembarco dificultoso, el campo cristiano se puso en movimiento, $y$, después de atravesar el poblado de Vélez de 1a Gomera, abandonado por sus moradores, se situó frente a la fortaleza del Peñón. Defendía el castillo una guarnición turca mandada por el renegado Ferret, en ausencia de su alcaide Cara-Mustafá. Las piezas de artillería de tierra y mar comenzaron a demoler bastiones y muros y los turcos se dieron a la fuga. E1 6 de septiembre las tropas cristianas entraban en la fortaleza. Fueron reparadas las murallas y quedó una guarnición bien abastecida ${ }^{1}$.

En el doc. I f. 4r 28-29 año I563, se menciona la plaza de Vélez como lugar de refugio de piratas; entre ellos, el turco Chucel. E1 doc. II del año 563 menciona al alcaide de Vélez como partícipe de la expedición contra nuestras costas. Gracias a nuestro documento IX, del año I564, tenemos un informe completo de la cabalgada que el alcaide de Vélez llevó contra Níjar y Torval.

También encontramos abundantes referencias al sistema defensivos de nuestras costas y a la milicia especial reglamentada en las conocidas ordenanzas valencianas y granadinas ${ }^{2}$. En el doc. IX, $4 \mathrm{r}_{20-22}$ se pregunta si vieron señales a ahumadas por tierra, y las escaramuzas $o$ encuentros con la gente de guerra soll frecuentes.

Muchas experiencias marineras - vientos dominantes, calas favorables, táctica de desembarco, planes de espionaje- están contenidas en nuestra selección de documentos, y a ellos remitimos.

Aspecto lingïistico

Los hemos valorado desde los siguientes apartados:

a) poliglotismo

El poliglotismo era bastante corriente en el Mediterráneo del siglo xvi y siempre estuvo bastante unido a la vida marinera de todos los

1 Vid. Diccionario de Historia de España. Madrid, 1952, t. II, pp. I393-4.

2 Vid. mi estudio Dos avisos de rebato en lengua catalana ( ${ }_{5} 60$ ) en $A F A$, I96I-2, XII-XIII, pp. 77-II5. 
tiempos. Recordemos, con Oliver Asín 1, que, en la comedia de Cervantes Los Baños de Argel, la joven Zahara aparece como novia de un futuro sultán. Muley Maluco; éste es Abd al-Malik (n. I54I, m. I578). En el Act. III de la comedia se muestra la simpatía y admiración por el famoso rey Maluco de la batalla de Alcazarquivir:

Moro muy famoso,
y en su secta y mala ley
es versado y muy curioso.
Sabe la lengua turquesca,
la española y la tudesca,
italiana y francesa,
duerme en alto, come en mesa
sentado a la cristianesca;
sobre todo, es gran soldado
liberal, sabio, compuesto
de mil gracias adornado.

E1 doc. $V$ nos presenta al cautivo Juan Nicolao, que tiene el habla cerrada, es decir, hablaba español con acento extranjero y resulta ser natural de Ragusa, de la Eslavonia, de aquella parte de Venecia. Recordemos el renegado esclavón o eslavo Agi Morato $H \bar{a} \hat{y} \hat{y} \bar{i}$ M $u$ ràd, suegro del rey Maluco, dueño siempre del gobierno y riqueza de Argel y musulmán sólo en apariencia ${ }^{2}$.

Nuestro Juan Nicolao, cuando le preguntan el credo y la salverregina, "dixo que los savía en su usança e lengua araguzesa, que es de la Esslabonia, e no obo persona que entendiese la dicha lengua».

Juan Andrés, napolitano, escapado de seis galeotas de turcos que estaban en la Mesa de Roldán, «habla claro castellano». Eil negro Mazote sabe lengua ciciliana y turquesca, y el capitán Pedro de Samaniego actúa de intérprete -es de suponer en lengua siciliana- para el interrogatorio.

Consecuencia del poliglotismo es el uso de la «lingua franca», mezcla de todas las lenguas que ya hemos scñalado en un pasaje del Quijote y que Haedo, en su Topographia, define como "una mezcla de varias lenguas christianas, y de bocablos que por la mayor parte son italianos

1 La hija de Agi Morato, p. Io.

2 Carta del British Museum, Additional Mss. 28.359, publicada por Hisnry DT: CAstries. Sonwes inédites de l'Histoive du Maroc, Première Série, Dynastie Saadienne, Archives et Bibliotheques d'Augleterre, t. I. Paris-Londres, I9I8, p. I54. Citada por OIIVIR Asín, La hija de Agi Morato, p. I4. 
y españoles, y algunos portugueses...». Pensemos en el sobrescrito de la cédula de cautiverio que presenta Juan Nicolao y que hemos transcrito más arriba.

\section{b) léxico}

Se podría trazar todo un perfil léxico del cautiverio; destacamos, de ese repertorio que figura en el Indice final, las siguientes palabras: amenja, $\mathrm{V}, \mathrm{IV}_{24}$ "anda por el navío de popa a proa dando de comer (de los galeotos) va sin hierros».

I, a forma amenja registrada junto a menja 'comida' en expresiones "servía de dar la menja, que era dar de comer a la gente», V, $4 \mathrm{v}_{1}$ se pueden relacionar con el cat. menjar 'comer', documentado desde los siglos XIII y xIV, y procedente del lat. m a n d i c a re $>$ mande(g)are $>$ mandyare $>$ menjar (Vid. Corominas, DCELC, III, p. 234). Por otra parte Menéndez Pidal, Origenes, p. 5II, cita, entre los galicismos usados por los mozárabes, manjar, «empleado por el cordobés Ben Cuzmán (Sim., p. 33I)». Corominas, DCELC, III, p. $234 \mathrm{~b}_{45-56}$, se inclina por el origen árabe de la forma $m$-nŷar citada por Simonet; señala el verbo náy ar 'preparar naŷîra', siendo la naŷîra 'leche mezclada con harina o mantequilla', y admite la posibilidad, en el árabe vulgar de España, del derivado verbal de la forma minŷar o mánŷar. En cuanto al árabe argelino y marroquí mánŷa citado por Simonet, afirma Corominas ser "galicismo o italianismo reciente». La $e$ del cat. menjar (ant. y mod.) es común a todos los dialectos catalanes (aun los accidentales) y reaparece en muchas hablas occitanas y aun francesas (Rom. VII, pp. 427-35); queda el italiano mangiare, provenzalismo que sustituyó al castizo manicare.

En esta encrucijada de formas vienen a plantear un nuevo interrogante amenja 'hombre que anda suelto por el barco dando de comer a los galeotos' y manja 'comida de los galeotos'. Para una interpretación correcta hemos de situar cada palabra en el texto del documento: "Preguntado que, pues que dize que es xristiano, que por qué lo traían los moros sin hierros e suelto, dixo que porque daba de comer a los xristianos, que se dize el amenja, porque el que tiene este cargo anda por todo el nabío, de popa a proa, dando de comer e no puede llevar hierros».

I a expresión "que se dize» introduce, por lo general, palabras árabes, que no son del uso común y corriente; así, en otros documentos del mismo Archivo de la Alhambra, se emplea dicha fórmula para las 
voccs: alhuc 'caja'; caçab 'ajorca'; joaras 'calzas de paño'; matruz 'bordado'; nazfia 'almohadas pequeñas'; quela 'mosquitero' ${ }^{1}$.

Iin todo caso, amonja debía ser palabra de uso poco frecuente en español y especial en la jerga del cautiverio; también «dar la menja» necesitaba aclaración para los oyentes españoles cuando el documento aclara: I, $4 v_{1-2}$ "servía de dar la menja, que era dar de comer a la gente».

Ahora cabe interpretar amenja y menja como formas aisladas de esa jerga mediterránea denominada «lingua franca», mezcla de todas las lenguas con la cual todos se entendían; de todas formas, el posible origen catalán no queda descartado; también las formas apuntadas por Corominas - todas figuran en el dic. ár. Belot-, pueden dar una explicación siempre que la menja y la naŷîa 'leche mezclada con harina o mantequilla' sean una misma cosa. No sabemos en este momento cuál era el tipo común de comida que los turcos daban a los esclavos de galeotas. Las citas de Simonet de la forma mánŷa en el árabe argelino y marroquí, junto a amenja y menja de nuestros documentos de cautivos, apoyan la sugerencia de Corominas de que el $m$-nŷar de Ben Cuzmán (S. XII) citado por Simonet, sea un derivado de náŷar 'preparar nầîra'.

monfies, V, $9 \mathrm{r}_{7}$ : "Me salí desimulado entre los turcos y unos monfies que avía recebido allí el mesmo capitán».

Como es sabido monfí del ár. vulgar muinfi 'desterrado', Corominas, III, p. 422, se documentaba por primera vez en I580, Hurtado de Mendoza, en Aut.; nuestro documento V es de ${ }_{5} 63$.

morabito, IX, $2 \mathrm{v}_{2}$ : "e un morabito predicándoles». Del ar. murâbit 'hermitaño'» murabito 'especie de anacoreta musulmán', Corominas, III, p. 429, señalaba como primera documentación el año I6oo, Mármol. E1 doc. IX es del año 1564.

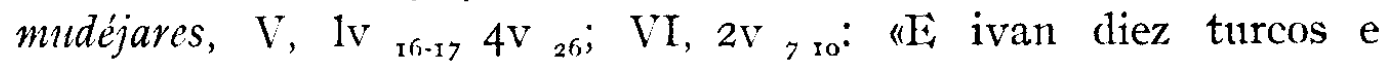
cinco mudéjares»; "Saltaron en tierra tres mudéxares que venían en las dichas galeotas de Argel».

Del ár. mudáŷyan 'aquel a quien se ha permitido quedarse', vid. Dozy, Gloss., 32I-2, Corominas señalaba como primera documentación el I57I, E. de Garibay; nuestros documentos son de $\mathrm{r}_{563}$.

1 Un estudio de las fórmulas con que se introducen palabras de origen árabe en documentos granadinos del siglo XVI, se puede ver al final de mi comunicación al I Congreso Internacional de Hispanistas, Oxford, 6-I I septiembre de I962, Escritura biling ïe en el Reino de Granada (S. XVI), segín documentos inéditos del Archivo de la Alhambra, pp. 373-374 de las Actas del Primer Congreso Internacional de Hispanistas. Oxford, I964. 
palangre, $\mathrm{V}, 2 \mathrm{r}_{7}$ : «e que vinieron derechos a la costa de Málaga e allí tomaron tres xristianos e una barca que, estaba pescando al $p a$ langre».

Hasta ahora palangre 'cordel del cual penden a trechos unos ramales con anzuelos en sus extremos, y que se cala en parajes de mucho fondo donde no se puede pescar con redes' $<$ cat. palangre (doc. barcelonés de I4I6, Moliné, Consolat de Mar, p. 355) < it. merid. palàngrisi, palàncastro < gr. polus 'mucho' ágkriston 'anzuelo', se documentaba por primera vez en lengua castellana en el año I793, vid. Corominas, III, p. $622 b_{6}$. El documento que manejamos es de ${ }_{5} 563$.

raheiz, VII, $3 \mathrm{v}_{20}$ : "Aguado es un hombre baxo, de cuerpo reheiz."

En el s. xvi había caído en desuso el ant. rahez 'barato', 'vil, bajo', 'fácil' > ár. rajị̂ 'barato', r. a doc. rafez, Berceo y refez y rehez. Juan de Valdés, I535 dice que raez está desechado, queda en coplas antiguas y en un refrán: "huésped que se combida, rece es de hartar».

E1 doc. VII del año I55I, redactado en Almería, revela el arcaísmo y conservadurismo léxico de esta zona andaluza.

\section{c) fraseología}

andar sin hierros, V, $1 \mathrm{v}_{20}$; cortado como moro, $\mathrm{V}, 1 \mathrm{r}_{28}, 1 \mathrm{v}_{24}$; cortar el capillo del miembro como moro, VI, 2r 25-26; echar al remo, IX, 4r ${ }_{13}$; echar la gente en tierra, IX, $2 \mathrm{~T}_{14}, 3^{\mathrm{r}_{9}}$; entrar mucho levante, IX, $2 \mathrm{~V}_{8.7}$; forcejar con el levante, IX, 2V 7 ; hacer aguaje, V, $9 \mathrm{r}{ }_{4}$; hacer cirimonia de moro, $\mathrm{V}, 4 \mathrm{~V}{ }_{11}$; hazer viaxe, $\mathrm{IX}, 3 \mathrm{r}_{16}, 3 \mathrm{~V}_{13}$; hirrado en la cadena al remo, $\mathrm{V}, 8 \mathrm{~V}{ }_{7}$; libro que traen de moros, $\mathrm{V}, 2 \mathrm{r}_{23}$ (díxoles bien el libro, $\left.\mathrm{IX}, 3 \mathrm{r}_{8}\right)$; poner a quistion de tormento, $\mathrm{V}, 5 \mathrm{~V}_{20-21}$; salir por espia, V, 6r ${ }_{9-10}$; tomar lengia , V, $5^{\mathrm{r}_{1}}$; VI, $2 \mathrm{~V}_{9}$; tornarse moro, $\mathrm{V}, 1 \mathrm{v}_{29}$.

El mundo de cautiverio en el «Quijote».

Nuestra breve incursión por el campo de cautiverio ha permitido señalar una serie de puntos de contacto entre el mundo de la realidad cotidiana, reflejado en nuestros documentos notariales, y el mundo de la ficción literaria; ello nos ha ayudado a descubrir el acierto estético del escritor en su proceso selectivo del mundo de la realidad cotidiana. Después de anotar la crudeza con que están consignados en los documentos los usos y costumbres de los bardaxas, encontramos delicado y prudente lo que Cervantes dice en el Quijote II, cap. LXIII 
cuando Ana Félix expresa, como cosa corriente y de todos conocida, el peligro que corría un mancebo tan hermoso en manos de aquellos torpes sodomitas.

Las cédulas de rescate de cautivos y las narraciones de esclavos escapados de las galeras turcas, son testimonios elocuentes de la angustia e inquietud en la vida española de aquella época; era algo que flotaba en el ambiente y que podía surgir en el momento menos sospechado; por ello, Cervantes, excautivo de Argel, no quiso silenciar sus experiencias personales y dio cabida en las páginas de su Quijote a la historia del Cautivo, inserta en la primera parte, y a la prodigiosa vida de Ana Félix, hermosa morisca, hija de Ricote, que aparece disfrazada como arráez o capitán de una galera turca; historia ésta no inserta o ingerida, como novela suelta o pegadiza, sino íntimamente unida al suceso de mayor trascendencia en la vida de don Quijote, al vencimiento del Caballero Andante en la playa de Barcelona por el Caballero de la Blanca Luna.

E1 medievalismo de don Quijote y su espíritu caballeresco no tienen cabida ahora en el nuevo mundo, tan extraño y distinto, que Barcelona ofrece al héroe. Nada tiene que hacer en este marco de guerra racionalizada cuyo centro ocupan las galeras, prodigiosos complejos bélicos servidos por fuerzas mercenarias y equipados con espantosas armas de fuego ${ }^{1}$. Pero este mundo, al parecer de equilibrio perfecto, se ve perturbado por la llegada de una galera turca cuyo arráez es Ana Félix, belleza y religiosidad femeninas, capaz de subvertir todos los valores y anular todas las razones de Estado. De labios de Ana Félix brota ante el loco idealista un nuevo mundo, en donde, a su parecer, todavía es posible la acción heroica y personal; es el mundo del cautiverio que Cervantes, autor, conocía tan a fondo y en cuyo crisol templó tan heroicamente su alma.

Ante los proyectos del Renegado para rescatar a Gaspar Gregorio - el bello cautivo que protegía su belleza en hábito de mujer-, considera don Quijote que sería mejor «que le pusiesen a él en Berbería con

1 VICENS LLORENS. Historia y ficción en el Quijote. p. 255, hace una acertada relación de las impresiones de don Quijote en el medio barcelonés: la urbe con sus gentes callejeras, la cabeza encantada, la imprenta, el mar y "las galeras, instrumentos de guerra, pero de una guerra racionalizada, de eficiencia y disciplina, con fuerzas mercenarias que obedecen como autómatas, y provistas de temibles armas de fuego; todo ello radicalmente opuesto al concepto medieval que un caballero andante como Don Quijote tenía de la guerra: basta recordar el discurso de las armas y las letras". 
sus armas y caballo; que él le sacaría a pesar de toda la morisma, como había hecho don Gaiferos a su esposa Melisendray. El realismo de Sancho sirve para destacar la verdadera situación del momento, ya que la empresa de Gaiferos fue empresa de "tierra firme», y ésta es empresa con la mar por medio. Al final, todos sabemos que la pericia de un renegado y el dinero de un morisco libertan a don Gregorio, mientras don Quijote sueña, paseando por la playa, mil lances y empresas en Berbería y tal vez espera el fracaso del Renegado para la nueva oportunidad que se le descubre. Los sueños de don Quijote se ven interrumpidos por la llegada del bachiller Sansón Carrasco disfrazado de Caballero de la Blanca Luna, quien reta y vence a nuestro héroe en noble lid.

E1 feliz regreso de don Gregorio y del Renegado ocurre cuando don Quijote todavía yacía en su lecho, triste y pensativo, sin poder apartar la tristeza de su vencimiento. Se alegra de la noticia, pero declara que se hubiera alegrado de "que hubiera sucedido todo al revés", porque le obligara a pasar a Berbería, donde, con la fuerza de su brazo, «diera libertad no solo a don Gregorio, sino a cuantos cristianos cautivos hay en Berberían. Pero el mismo don Quijote recuerda su vencimiento, con la prohibición de tomar arma en un año, y lo baldío de sus promesas en esta situación.

Los documentos que hemos presentado son harto prolijos en detalles sobre la reducción de los renegados al seno de la Santa Iglesia; Cervantes expone estos mismos asuntos "limitadamente y con solas las palabras que bastan a declararlos», fiel en esto a su programa expuesto en el cap. XXXII de la 2. ${ }^{a}$ parte. Así la reducción del Renegado se presenta con un verdadero alarde de selección de la realidad y economía de medios expresivos (II, cap. LXV, p. I35): «Reincorporóse y redújose el Renegado con la Iglesia, y de miembro podrido, volvió limpio y sano con la penitencia y el arrepentimiento».

Produce una impresión extraña y melancólica el final del capítu1o LXV de la segunda parte: don Quijote y Sancho vuelven a la aldea, tras la derrota, mientras Ana Félix, separada temporalmente de su amado don Gregorio, espera, con su padre Ricote, las diligencias que don Antonio haga en la Corte, para conseguir el favor real contra el decreto de expulsión que el gran Felipe III, con inaudita prudencia, había confiado al gran don Bernardino de Velasco, conde de Salazar. Ricote sabe bien que el decreto mencionado es inapelable y justificado "para que España quede limpia y desembarazada de los temores en que nuestra muchedumbre la tenía». Las promesas de don Antonio: "Una por una, yo haré, puesto allá, las diligencias posibles, y haga el 
cielo lo que más fuere servido", pueden ser objeto de interpretaciones variadas; para Vicente Lloréns ${ }^{1}$, Cervantes bien sabía que el amor no podía triunfar sobre la razón de Estado, y por eso queda inconcluso el episodio: "La hermosura de Ana Félix opera milagros sobre los hombres en cuanto personas, aunque sean virreyes, pero carece de poder sobre la razón de Estado, sobre lo institucional». Cabe también otra interpretación del mismo pasaje; el mismo Cervantes podía muy bien pensar que los decretos generales en casos excepcionales dejan muy bien de cumplirse. Esta conjetura encuentra apoyo indiscutible en una serie de testimonios históricos.

Hemos de partir del hecho cierto de que la expulsión de los moriscos, llevada a cabo entre $\mathrm{r} 609$ y $\mathrm{I} 6 \mathrm{r} 3$, no fue definitiva ni radical; para Caro Baroja ${ }^{2}$ "queda oculta una realidad más compleja, que nunca podrá ya ser aclarada»; "no podemos determinar el número de los que quedaron protegidos por autoridades locales ni el de los que volvieron, más o menos subrepticiamente, aunque sabemos que su retorno en grupos aislados fue un hecho que incluso se halla como tema en un pasaje famoso de nuestra literatura». Alude Caro Baroja al morisco Ricote, tendero, vecino y amigo de Sancho Panza.

A la vista de este texto con alusión al interés de determinadas autoridades locales en la permanencia de ciertos moriscos, sería conveniente recordar la actitud del virrey de Barcelona ante los moriscos Ana Félix y Ricote; es una actitud tierna y compasiva: «E1 Virrey, tierno y compasivo, sin hablarle palabra, se llegó a ella y le quitó con sus manos el cordel que las hermosas de la mora ligaba" (cap. LXIII, 2. ${ }^{a}$ parte, t. VIII, p. II2 10-12). E1 General también queda ablandado por las lágrimas de la bella morisca: "Una por una, vuestras lágrimas no me dejan cumplir mi juramento: vivid, hermosa Ana Félix, los años de vida que os tiene determinado el cielo...) (p. II4 21-23). No menor es la solicitud que el Virrey muestra por el buen acomodo de los dos: "y don Antonio Moreno se llevó consigo a la morisca y a su padre, encargándole el Virrey que los regalase y acariciase cuanto le fuese posible; que de su parte le ofrecía lo que en su casa hubiese para su regalo. Tanta fue la benevolencia y caridad que la hermosura de Ana Félix infundió en su pecho» (p. s. II5-II6).

Por fin el Virrey expresa su voluntad de que padre e hija quedaran en España, "pareciéndoles no ser de inconveniente alguno que que-

$1 \quad$ Historia y ficción en el Quijote, p. 257.

$2 \quad$ Los moriscos del reino de Granada. Madrid, I957, p. 249. 
dasen en ella hija tan cristiana y padre, al parecer, tan bien intencionado" (p. $136_{1-2}$ ).

En caso de resultar infructuosas las gestiones de don Antonio en la Corte -y ya el mismo Ricote ve en el conde de Salazar un justo e irreductible bastión- ¿pudieron Ana Félix y su padre Ricote quedar bajo la protección del Virrey, como tantos otros moriscos ya senalados? Hay algún dato concreto que conviene señalar. Volvamos a la Historia y a nuestros documentos.

Después de la sublevación de los moriscos en las Alpujarras se ordenó la expulsión del reino de Granada de todos los cristianos nuevos. Comenzó el día de Todos los Santos de I570 ${ }^{1}$. Don Juan de Austria escribe cartas desde Guadix a Felipe II; una, del día 5 de septiembre, da ya noticia de la saca. En el Archivo de la Alhambra encuentro copia de una cédula y provisión del mismo don Juan de Austria, fechada en Guadix a 5 de noviembre de 1570 , autorizando a Damián Hris, cristiano nuevo, a vivir y morar libremente en Granada, con su casa y su familia, no obstante las últimas disposiciones de destierro (doc. XI).

Otra cédula, fechada en Granada, a 29 de noviembre de 1570 , otorgada por el mismo don Juan de Austria, autoriza a Hernando El-Baizi a permanecer en Granada con su familia, por su «lealtad y fidelidad" y por "ser honbre pacífico y de buen bibir", no obstante los bandos que se habían hecho para que salieran de la ciudad los cristianos nuevos (doc. XII).

La expulsión no fue radical y todavía, en I6Io, salieron de Granada seiscientos moriscos ricos ${ }^{2}$, y entre $\mathrm{I} 775$ y 1776 el viajero inglés Joseph Towsend, a su paso por Granada, conoció al inquisidor Cardoqui, y tuvo noticia de que en $I 726$ se procesaron nada menos que a 360 familias granadinas, acusadas de profesar al mahometismo encubiertamente, acusación que resultó ser verdadera ${ }^{3}$.

Con estos testimonios ya no resultará muy arriesgado imaginar un feliz desenlace en la historia de los moriscos Ana Féliz y Ricote, casada la primera con don Gregorio y viviendo en España por así merecerlo hija tan bella y tan cristiana y padre, al parecer, tan bien intencionado, "hombre pacifico y de buen vivir", como dijera don Juan de Austria del morisco granadino Hernando El-Baizi.

De todas formas el episodio de Ana Félix -como señala Joaquin

1 Caro Baroja, op. cit. p. 206, nota 5 .

2 Caro Baroja, op. cit. p. 213.

3 Caro Baroja, op. cit. p. 260 y Joseph Townsend. A journay through Spain in years 1786 and 1787 , III, Londres, I792, pp. 82-84. 
Casalduero ${ }^{1-}$ - se divide en dos partes (caps. LXIII y LXV) para encuadrar «la aventura que más pesadumbre dió a Don Quijote (cap. LXIV)". E1 mismo Casalduero ${ }^{2}$ señaló cómo la gran novela cervantina transcurre entre casas y salones y "cómo en esta vida política y urbana se abre de repente el mirador que da al mar y cómo esta abertura se llena con una escena de una pareja en Argel». En la primera y en la segunda parte del Quijote se deja entrever Argel y el mundo de cautiverio. Mientras el Caballero Andante duerme, Ruy Pérez de Viedma cuenta su vida; en el Quijote de 1615, Ana Félix y don Gregorio aparecen rodeados por la codicia y lascivia del rey de Argel. Es la misma codicia y lascivia que reflejan los documentos que anteriormente hemos comentado.

Con los documentos de cautivos argelinos que ahora ofrecemos hemos intentado captar un aspecto de la realidad y acercarnos con esa realidad del cautiverio a la obra cervantina. No intentamos ahora afrontar el problema de la realidad en las obras de Cervantes, tan certeramente planteado por Américo Castro ${ }^{3}$, Richard L. Predmore ${ }^{4}$, Ortega y Gasset ${ }^{5}$, A. A. Parker ${ }^{6}$, Joaquín Casalduero ?, Leo Spit-

1 En su libro Sentido y forma del Quijote. Madrid, I948, p. 362.

2 Op. cit. pp. 360-I.

3 El pensamiento de Cervantes. Madrid, 1925, p. 79: «Si hay en Cervantes una producción general, previa a las demás, es la de cómo sea la realidad objetiva", y más adelante, p. 80: «Don Quijote es el depositario del tema de la realidad oscilante». En I947 Américo Castro cambia en su punto de vista; ya no cree que a Cervantes le interese en ocasiones determinar cuál fuera la realidad yacente bajo la fluctuación de las apariencias: "Mas no es el problema de la verdad o del error lógico lo que al autor preocupa, sino hacer sentir cómo la realidad es siempre un aspecto de la experiencia de quien le está viviendo", en Miguel de Cervantes Saavedra. Homenaje de "Insula" en el cuarto centenario de su nacimiento, I547I947, p. 35. Por fin, en 1960, Américo Castro se expresa asi: «Según el autor del Quijote, la realidad de la existencia consiste en estar recibiendo el impacto de cuanto pueda afectar al hombre desde fuera de él, y en estar transformando tales impresiones en procesos de vida exteriorizables». Hacia Cervantes, Madrid, 1960, p. 271.

4 El mundo del Quijote. Madrid, I958, capitulo IV, La realidad, pp. 77-I I 2 y El problema de la realidad en el Quijote, NFRH, I953, VII, pp. 489-498. Cervantes cuenta las aventuras «de tal modo que el lector sepa siempre cuál es la realidad objetiva». El mundo del Quijote, p. 79.

5 Meditaciones del Quijote. 5. a ed. Madrid, I958, pp. 57-8: «el placer de la visión, de recorrer, de palpar con la pupila la piel de las cosas, es el carácter diferencial de nuestro arte. No se le llama realismo, porque no consiste en la acentuación de la res, de las cosas, sino de la apariencia de las cosas. Mejor fuera denominarlo aparentismo, ilusionismo, impresionismo».

- El concepto de la verdad en el Quijote, RFE, I948, XXXII, pp. 287-305.

7 Sentido y forma del Quijote. Madrid, 1949 y La composición de "E.l Ingenioso Hidalgo Don Quijote de la Mancha», RFH, II, p. 323 y ss. 
zer ${ }^{1}$, Amédée Mas ${ }^{2}$, todos en continuo esfuerzo y tensión por 1legar a una adecuada interpretación de la novela maestra de Cervantes; nos contentamos por ahora con señalar que Cervantes, como excautivo de Argel, no pudo olvidar esta experiencia personal del mundo de cautiverio y por ello su novela abre dos grandes miradores; uno, en la Mancha; con 1a historia del Cautivo; otro, en la playa de Barcelona, por donde penetra una brisa mediterránea, llena de salinas claridades, incidentes y vicisitudes, miseria y grandeza de la vida de cautiverio, donde la Belleza es la mejor defensora de la causa de los moriscos y donde Lascivia y Codicia encadenan a bardaxas y amenjas con tan pesadas cadenas como las que atan al galeote. Los documentos dan pormenores y detalles de usos y costumbres que en la novela cervantina están levemente insinuados por el autor con la transparencia cristalina de múltiples reflejos y variadas irisaciones de la obra de arte ${ }^{3}$.

Juan Martínez Ruiz.

1 Perspectivismo lingǘstico en el Quijote, pp. 16r-225 de su libro Lingüistica e Historia Literaria. Madrid, 1955.

2 La théme de la réalité oscillante dans Don Quichotte, en Hommaged Ernest Martinenche. Paris, sin fecha, pp. 375-38o: «ce qui est variable, oscillant, ondoyant, chatoyant pour Cervantès, ce sont les images, les représentations de la réalité, ce n'est pas la réalité elle-même».

3 LEO SPITZER. Perspectivismo lingüistico en el Quijote, p. 225, concluye así su valioso estudio: "Hay aqui, en el mundo que ha creado, un aire vivificante con el que podemos llenar nuestros pulmones y con el que se afianzan nuestros sentidos y nuestro juicio individuales, y hay la transparencia cristalina de un creador artístico en sus múltiples reflejos y variadas refracciones». 


\section{A P E N D I E}

\section{I}

Año I553. Valladolid.

Cédula de rescate de Alonso de Quesada

cautivo en Argel.

Archivo de la Alhambra, L-6-63.

\section{El Principe:}

1 Conde de Tendilla, pariente, capitán General del reino de Granada. Por parte de Juana de la Cruz, muger de ${ }^{3}$ Alonso de Quesada, vezina de la ciudad de Granada, nos ha sido hecha relación que ha seys meses, poco más o menos, ${ }^{2}$ que ciertos cosarios turcos enemigos de nuestra santa fe católica, captivaron al dicho Alonso de Quesada, su marido y le $^{4}$ tienen preso en Argel, y porque no tiene con que se rescaptar nos suplicó y pidió por merced que de la renta de los abizes $\mathrm{de}^{5}$ las Alpuxarras de esse dicho reino, que está dedicada para rescapte de captivos y otras obras pías, le hiziese alguna merced ${ }^{6}$ y limosna, o como la nuestra metced fuese, y nos acatando lo susodicho y no haviéndose dado hasta agora cosa alguna ${ }^{7}$ de los dichos abizes para rescapte del dicho Alonso de Quesada havemos havido por bien que se le den cincuenta ducados, ${ }^{8}$ que montan diez y ocho mill y sietecientos y cincuenta maravedís, por ende yo vos encargo y mando que constandoos ${ }^{9}$ por información ser su relación verdadera y dándose por su parte, o de la persona o personas que tuvieran encargo de ${ }^{10}$ rescaptar, al dicho captivo fianças legas, llanas y abonadas, que dentro de ciento y ochenta días lo rescaptará, 11 traerá y presentará ante vos, o volberán y restituirán a poder de la persona en quien estuvieren depositadas las ${ }^{12}$ rentas de los abizes, los dichos cincuenta ducados, proveais que el depositario, o persona que tiene en su poder la renta ${ }^{13}$ de los dichos abizes, acude con ellos a la dicha Juana de la Cruz o a quien su poder aviere, y gelos dé y pague en dineros ${ }^{14}$ contados, y para ello le dad vuestras cartas las quales mandamos que sean cumplidas y executadas, "que si necesario es 15 os damos poder cumplido, qual al caso convenga, lo qual mandamos que assí se haga y cumpla, tomando los ${ }^{18}$ contadores mayores de quentas de su Magestad la razón de esta mi cédula. Fecha en Valladolid a quinze de deziembre de ${ }^{17}$ mill y quinientos y cinquenta $y$ tres años. Yo el Príncipe. ${ }^{18}$ Por mandado de su Alteza. Fernán Bargas. 
Año I558. Valladolid.

Cédula de rescate de Gonzalo de Aguilar

cautivo en Argel

Archivo de la Alhambra, L-6-632.

E1 Rey:

` Conde de Tendilla, pariente nuestro, capitán general del nuestro reino de Granada. Por parte de Gonçalo de Aguilar ${ }^{9}$ vezino de la ciudad de Granada, nos ha sido hecha relación que havrá tres años, poco más o menos, que Sebastián ${ }^{3}$ de Aguilar, su hijo, fue preso por los turcos y lo está en Argel, y porque no tiene con que lo rescaptar, nos suplicó y ${ }^{4}$ pidió por merced que de la renta de los habizes de las Alpuxarras de esse reino, que está dedicada para rescapte de ${ }^{b}$ captivos y otrás obras pías, le hiziessemos alguna merced y limosna, o como la nuestra merced fuese, $y$ nos acatando ${ }^{6}$ lo susodicho y no haviéndose hasta aora dado ninguna cosa para el rescapte del dicho Sebastian de Aguilar, ${ }^{7}$ su hijo, havemos havido por bien que se le dé cincuenta ducados, que montan diez y ocho mill y setecientos ${ }^{8}$ y cincuenta maravedis. Por ende yo vos encargo que constandoos por información ser su relación ver- ${ }^{9}$ dadera y dándose por su parte o de la persona o personas que tuvieren cargo de rescaptar al dicho Sebas- 10 tián de Aguilar, fianças legas, llanas y abonadas, que dentro de cient y ochenta días desde que se le en- ${ }^{11}$ tregaren los dichos dineros en adelante, lo rescaptarán y traerán y presentarán ante vos, o bolverán y ${ }^{\mathbf{1 2}}$ restituirán a poder de la persona enquien estuvieren depositadas las dichas rentas de los dicho havizes, ${ }^{13}$ los dichos cincuenta ducados, proveais que el depositario o personas que tuvieren cargo de la renta de ${ }^{14}$ los dichos havizes, acuda con los dichos cincuenta ducados al dicho Gonçalo de Aguilar, o a quien su ${ }^{15}$ su poder huviere, y ge los dé y pague en dineros contados, y para ello le dad vuestras cartas, las quales ${ }^{16}$ mandamos que sean cumplidas y executadas, que si necesario es, os damos poder cumplido, qual al ${ }^{17}$ caso convenga, lo qual mandamos que assí se haga y cumpla, tomando los nuestros contadores mayores ${ }^{18}$ de quenta y Joan de Galarça, nuestro criado, la razón desta nuestra cédula. Fecha en Valladolid a XXVIII de ${ }^{19}$ agosto del año mill y quinientos y cinquenta y ocho del nascimiento de nuestro Señor y Salvador Iehsuxripto. 20 Yo la Princesa.

21 Tomose la razón de esta cédula de su ${ }^{22}$ Magestad en los sus libros de las quentas, ${ }^{53}$ en Valladolid a diez de setiembre de MDLVIII años. ${ }^{64}$ Por mandado de su Magestad.

25 Tomó la razón Joan de Galarça.

26 Merced a Gonçalo de Aguilar vecino de Granada de $\mathrm{L}$ ducados enn la renta de los havizes, para ${ }^{27}$ rescapte de un hijo suyo. 
Año 1559. Torquemada (Palencia)

Cédula de rescate de Sebastián de Najara cautivo en Argel en la jornada del Conde

de Alcaudete.

Archivo de la Alhambra, L-6-636.

El Rey:

1 Conde Tendilla, pariente nuestro, capitán general del nuestro reino de Granada, por parte de Joan López de Nájara, vezino ${ }^{2}$ de la ciudad de Granada, nos lia sido hecha relación que Bastián de Najara, su hermano, captivaron los moros en la ${ }^{3}$ jornada que el conde de Alcaudete nuestro capitán general que fue de los tercios de Tremecén y Túnez y alcaide de la ${ }^{4}$ ciudad de Orán, hizo en Africa el año pasado de mill y quinientos y cinquenta y ocho y que al presente está en Argel ${ }^{5} \mathrm{y}$ porque no tiene con que se rescaptar, nos suplicó y pidió por merced, que de la renta de los hazives de las Al- ${ }^{6}$ puxarras de esse dicho reino, que está dedicada para rescapte de captivos y otras obras pías, le hiziessemos algu- ${ }^{7}$ na merced y limosna o como la nuestra merced fuesse, y nos acatando lo susodicho y no haviendo dado hasta agora ${ }^{8}$ ninguna cosa para rescapte del dicho Bastián de Nájara, havemos havido por bien que se le den cincuenta ducados, ${ }^{9}$ que montan diez y ocho mill y setecientos y cinquenta maravedis, por ende yo os encargo y mando que constan- ${ }^{10}$ doos por información ser su relación verdạdera, y dándose por su parte o de la persona o personas que tuvie- ${ }^{11}$ ren cargo de rescaptar al dicho Bastián de Nájara, fianças legas, llanas y abonadas, que dentro de ciento y ${ }^{12}$ ochenta días lo rescaptarán y traerán y presentarán ante vos, o bolverán y restituirán a poder de la perso- ${ }^{13}$ na o personas en quien estuvieren depositadas las rentas de los havizes, los dichos cinquenta ducados, proveais ${ }^{14}$ que el tal depositario, o personas, acudan con los dichos cinquenta ducados al dicho Joan López de Nájara, o a quien ${ }^{15} \mathrm{su}$ poder huviere y ge los dé y pague en dineros contados y para ello le dad las cartas que fueren menester, ${ }^{16}$ las cuales mandamos que sean cumplidas y executadas, que si necesario es para ello, os dalos poder ${ }^{17}$ cumplido qual al caso convenga, lo qual mandamos que assi se haga y cumpla, tomando la razón ${ }^{18} \mathrm{~d} e$ ella Joan de Galarça, mi criado. Fecha en Torquemada a ocho de mayo de mill y quinientos y cincuen- ${ }^{19}$ ta y nueve años. Yo la Princesa. ${ }^{20}$ Por mandado de su Magestad. Ferrán Bargas. 21 Tomó la razón Joan de Galarça.

\section{IV}

Año 1560. Archidona (Málaga).

Cédula de rescate de Iñigo Delgado, alférez de la compañia de Hernán Pérez del Pulgar en la jornada del Conde de Alcaudete.

Archivo de la Alhambra, L-6-6 $3_{8}$.

Muy illustrísimo Señor:

${ }^{1}$ Iñigo Delgado, vecino de la villa de Alchidona, alférez que fue de la compañía de Hernán Pérez ${ }^{2}$ del Pulgar en la jornada del conde de Alcaudete, ante vuestra señoria presentôesta cédula de su Magestad ${ }^{3}$ por la qual me haze merced de mandar 
me dar en los habices de este reino, cinquenta duca- ${ }^{4}$ dos, para ayuda a mi rescate. Pido y suplico a vuestra señoria la mande cumplir y cumpliéndola ${ }^{5}$ me mande librar y pagar en los dichos habices y receptor $\mathrm{d} e$ ellos los dichos cinquenta du- cados, y estoy presto de hazer las diligencias necesarias para lo qual, etcétera.

${ }^{7}$ En la Alhambra a veinte e cinco de noviembre de ${ }^{8}$ mill e quinientos e sesenta años ante el muy illustre señor don Luis Hurtado ${ }^{\circ}$ de Mendoça teniente de capitán general del reino de Granada, en lugar y por ${ }^{10}$ absencia del muy illustre señor conde de Tendilla 11 capitán general del dicho reino de Granada, mi señor ,... etc.

\section{V}

Año 1563. Mojácar (Almería).

Cautivo escapado de una galeota de turcos.

Archivo de la Alhambra, L-I22-I2.

f. Ir ${ }^{1}$ En la ciudad de Moxácar veinte e dos dias del mes de ${ }^{2}$ abril de mill e quinientos y sesenta e tres años, por no estar ${ }^{3}$ en esta ciudad la justicia d $e$ ella al presente, en presencia de mí "el escrivano e testigos yuso escritos, paresció Francisco de Alcaraz ${ }^{5}$ vecino de esta ciudad y esibió y truxo un hombre mancebo, doblado, ${ }^{6}$ cariharto, que le apunta la barva, que tiene la habla cerrada ${ }^{7}$ que dixo que oy dicho día, a ora del medio día, poco más ${ }^{8}$ o menos, estando el dicho Almaraz e Juan Rridao el Saludador ${ }^{\circ}$ en medio de la ranbla de Macenas, encima del Garrobo ${ }^{10}$ junto al camino de la mar, vieron venir al dicho honbre, la ${ }^{11}$ ranbla abajo, solo, sin armas algunàs $\mathrm{y}$ él dixo que ${ }^{12}$ era xristiano e que esta noche pasada se avia huido de ${ }^{13}$ un navio de moros de la cala de San Pedro donde está un ${ }^{14}$ pozo. $\mathrm{E}$ como vieron que venía en ábito de turco e ${ }^{15}$ hablava cerrado, como moro, lo truxeron a esta cibdad ${ }^{15}$ para entregallo a la justicia, para que se aberigue ${ }^{16}$ quien es el dicho hombre e averiguándose sea turco ${ }^{17} \mathrm{o}$ moro pide se le adjudique por suyo y lo demandó ${ }^{18}$ e pidió justicia e testimonio. Testigos Diego de Belmonte 19 e Juan de Belmonte e Diego, vecinos de esta ciudad.

${ }^{20} \mathrm{Y}$ el dicho honbre hesibió una corona de oro y seis reales ${ }^{21}$ en plata, los dos de a dos y los dos senzillos e dos ${ }^{22}$ anillos de plata.

${ }^{23}$ Después de lo suso dicho en la dicha ciudad de Moxácar ${ }^{24}$ este dicho día ines e año suso dicho el muy noble señor ${ }^{25}$ Hernando de Belmonte el Moço requeridor alcalde de esta cibdad ${ }^{26}$ hallando preso en la carcel de esta cibdad al dicho honbre ${ }^{27}$ que truxo a esta ciudad el dicho Francisco de Almaraz y estando ${ }^{11}$ presente el señor Iorenzo Mateo alcaide de esta cibdad, al qual ${ }^{28}$ miraron si estava cortado como moro, y no se halló ${ }^{29}$ cortado. $Y$ le fue preguntado si es xristiano o moro, el ${ }^{30}$ qual dixo que es xristiano e hijo de xristiano e que quiere morir ${ }^{31}$ xristiano. Y el dicho señor alcalde le tomó e recibió ju- ${ }^{32}$ ramento en forma de derechoy le fueron hechas las ${ }^{33}$ preguntas siguientes por su lengua, que habla castellano ${ }^{34}$ algo cerrado.

36 Preguntado de donde es e cuyo hijo es e como se llama, dixo que ${ }^{25}$ se llama Juan de Nicolao, hijo de Nicolao, aragurés y su madre se $^{37}$.

f. Iv. ${ }^{1}$ Preguntado que quanto a que salió de su tierra, dixo que abrá ${ }^{2}$ más de doze años, que salió de ocho años de su tierra. ${ }^{8}$ Preguntado donde a andado todos los dichos doze años, ${ }^{4}$ dixo que a andado por la mar, en una nave napole- 
tana, con ${ }^{5}$ uno que se llamava Marian Sardo, patrono de la dicha nabe, ${ }^{6}$ más de diez años. Yendo de Nápoles lo catibaron los 7 moros a este confesante e a treinta e ocho honbres, ${ }^{8}$ que eran siete galeotas de moros, y los llevaron ${ }^{\circ}$ el viaje y después los llevaron a Argel e a estado ${ }^{10}$ catibo cinco años en Argel y en viages que lo an llevado ${ }^{11}$ los moros.

12 Preguntado donde se desenbarcó este confesante e de ${ }^{13}$ qué manera se salió de los moros, dixo que anoche ${ }^{14}$ a tres oras de la noche, saltaron los turcos de una ${ }^{15}$ galeota, en la cala de San Pedro a tomar agua al ${ }^{16}$ pozo de Ocho Ali. E ivan diez turcos e cinco mudé- 17 jares, con barriles, a tomar agua, y éste que declara ${ }^{18}$ dexó el barril entre unas cañas y se huyó a la mon- ${ }^{19}$ taña, para venirse en tierra de xristiano, por ser ${ }^{20}$ xristiano como era, porque andava sin hierros.

21 Preguntado que pues que dize que es xristiano, que por qué 22 lo trafan los moros sin hierros e suelto, ${ }^{23}$ dixo que porque daba de comer a los xristianos que se ${ }^{24}$ dize el amenja, porque el que tiene este cargo anda ${ }^{25}$ por todo el nabío, de popa a proa, dando de ${ }^{26}$ comer e no puede llevar hierros.

27 Preguntado si los dichos moros le abian dicho a este confesante ${ }^{28}$ y este confesante les abia prometido que se ${ }^{29}$ avia de tornar moro, dixo que Chuçe, su ${ }^{30}$ amo, le daba mala bida porque fuese moro, ${ }^{31}$ y este confesante le dezia con la boca que sí ${ }^{33}$ sería moro, pero que con el coraçón no porque es xristiano.

${ }^{33}$ Preguntado que pues dezía que abía de ser moro ${ }^{24}$ como no lo cortaron los moros. Dixo que no lo cortaron hasta que renegase.

35 Preguntado si renegó este confesante de nuestra santa fe ${ }^{\text {s6 } \ldots . . . . . . . ~}$

(f2r) 1 bautizado como xristiano por el dicho de su padre ${ }^{2}$ y de su madre.

${ }^{3}$ Preguntado quanto a que salió de Barbería el dicho navio de moros dixo que salió de Tetuán el dicho bagel 5 solo diez o doze dias a, e que vinieron derechos ' a la costa de Málaga, e allí tomaron tres xristianos ${ }^{7}$ e una barca que estaba pescando al palangre ${ }^{8}$ e que los tomaron antes de medio día, una legua ${ }^{9}$ fuera de Málaga e que los xristianos pen- 10 saron que hera varca de xristianos, porque iba con la ${ }^{11}$ vela pequeña $y$ es el bagel pequeño de catorze ${ }^{13}$ vancos. E luego les corrió fortuna un día e una noche e vinieron a parar al ${ }^{\mathbf{1 3}}$ cabo de Gata, a los quatro o cinco días e de alli ${ }^{14}$ vinieron hasta la cala de San Pedro por las ${ }^{15}$ calas adelante.

${ }^{16}$ Preguntado si los moros del dicho bagel an saltado ${ }^{17}$ en tierra a hazer algún asalto, dixo que no an ${ }^{18}$ osado saltar los turcos en tierra de miedo ${ }^{19}$ de don Juan, capitán de Almería.

${ }^{20}$ Preguntado a qué venían los dichos turcos a esta costa, ${ }^{21}$ dixo que vienen con intento de saltear e robar ${ }^{22}$ en esta costa a los xristianos y engañar ${ }^{23}$ con la barca, quando les digan bien las suertes ${ }^{24}$ del libro que traen de moros.

${ }^{25}$ Preguntado si se an enbarcado en el dicho vagel ${ }^{26}$ algunos moriscos, dixo que ayer después de ${ }^{27}$ anochecido, veinte e un días del presente ${ }^{28}$ mes de abril, se enbarcaron en el dicho ${ }^{29}$ vagel cinco moriscos, los quatro con vallestas ${ }^{30}$ y el uno con un arcabuz e que se enbarcaron ${ }^{31}$ en Rodalquilar porque dichos moros avian ${ }^{32}$ salido por almagra cabo el castillo de Ro- ${ }^{33}$ dalquilar e vieron venir los moriscos hazia ${ }^{34}$ ellos e creyendo que heran soldados bolvieron ${ }^{35}$ los turcos a la mar huyendo. E luego llegaron $\operatorname{los}^{26}$ dichos moriscos a la mat e dixeron que se quedaran (f. $2 v$ ).

(f. 2v) 1 Preguntado de donde son los dichos moriscos, dixo ${ }^{2}$ que los dichos moriscos dixeron que heran de Almería ${ }^{3}$ e que los moros les preguntaron a los mo- 
riscos por ${ }^{4}$ don Juan e por las galeras y ellos les dixeron que ${ }^{5}$ don Juan estava en Almería e que no abía nueba ${ }^{6}$ de galeras.

7 Preguntado si en Tetuán avía nueba que estava Orán ${ }^{8}$ cercada de moros, e quantos navios están sobre Orán, ${ }^{\circ}$ dixo que nueba avía que estaba el campo de ${ }^{10}$ los moros sobre Orán e que por la mar la tenian ${ }^{11}$ cercada con cinquenta navios.

12 Preguntado si se dezía quanto tiempo avian de ${ }^{13}$ tener el cerco sobre Orán, dixo que no lo ${ }^{14}$ sabe más de que es cosa cierta que está cercada ${ }^{15}$ Orán y se dezía entre los moros.

${ }^{16}$ Preguntado quantos nabíos y bageles ay en Tetuán ${ }^{17}$, dixo que abía quatro vageles, pero que no es- 18 taba ninguno armado.

${ }_{19}$ Preguntado declare la verdad si el dicho navío ${ }^{30}$ viene de Orán de los otros navíos que están ${ }^{21}$ sobre Orán e si benian los turcos del ${ }^{22}$ dicho bagel a tomar lengua si ba socorro ${ }^{23}$ del xristiano a Orán, dixo que no viene sino de ${ }^{24}$ Tetuán, como tiene declarado, a hurtar ${ }^{25} \mathrm{e}$ robar e que ésta es la verdad so cargo ${ }^{26} \mathrm{del}$ juramento que fecho tiene. No lo firmó por- ${ }^{27}$ que dixo que no sabía escrevir, firmolo el dicho ${ }^{28}$ señor alcalde de su nonbre. Hernando de Belmonte... ${ }^{29}$ Andrés de la Cadena, escrivano público.

${ }^{39}$ E luego el dicho señor alcalde dixo que mandava ${ }^{31}$ y mandó a Francisco de Nabarrete, alguazil mayor ${ }^{82} \mathrm{~d} e$ esta cibdad e allcaide de la carcel d $e$ ella, ten$\mathrm{ga}^{33}$ preso e a buen recaudo al dicho Juan de Nicolao ${ }^{34}$ con prisiones, de manera que no se baya ni absente ${ }^{35}$ so pena que sea a su culpa e cargo e que pagará ${ }^{36}$ los intereses e daños que sobre ello se le ${ }^{37}$ recabaren e así lo proveyó e mandó e firmó de su ${ }^{38}$ nonbre. Testigos Diego de Belmonte e Francisco de Almaraz, (f. $3^{\text {r) }}{ }^{1}$ vezinos de esta cibdad. Hernando de Belmonte, Andrés ${ }^{2}$ de la Cadena, escrivano público.

${ }^{3}$ F, luego yo, el dicho escrivano, notifiqué el dicho abto ${ }^{4}$ de suso al dicho Francisco de Nabarrete, alguazil mayor ${ }^{5}$ e allcaide de la carcel de esta cibdad, el qual dixo ${ }^{6}$ que está presto de lo tener preso con las pri- ${ }^{7}$ siones que tiene. Testigos los dichos. Andrés de la ${ }^{8}$ Cadena, escrivano público.

9 Luego el dicho señor alcalde manđó que, de los ${ }^{10}$ dineros del dicho honbre, se le den al dicho ${ }^{11}$ alguazil mayor, dos reales en quenta de ${ }^{10}{ }^{12}$ alimentos que le dé al dicho honbre. E al dicho ${ }^{13}$ Francisco de Almaraz le mandó dar dos reales de ${ }^{14}$ su trabaxo de aver traido desde la ${ }^{15}$ rambla de Macinas a esta cibdad el dicho ${ }^{16}$ honbre. $\mathrm{E}$ así yo el dicho escrivano di e pagué a los ${ }^{17}$ suso dichos los dichos quatro reales. Testigos los ${ }^{18}$ dichos Hernando de Belmonte. Andrés de la ${ }^{19}$ Cadena, escrivano público.

${ }^{20}$ Después de lo suso dicho, en la dicha cibdad ${ }^{21}$ de Moxácar a veinte e ocho días del mes ${ }^{22}$ de abril del dicho año el magnifico señor licenciado, Rodrigo de ${ }^{23}$ Herrera, alcalde mayor d $e$ esta ciudad y en presencia de ${ }^{24} \mathrm{mi}$, el dicho escrivano, hallando preso al dicho Juan ${ }^{25}$ Nicolao, al qual preguntó quantos años tiene ${ }^{26}$ dixo que hasta veinte e quatro o veinte ${ }^{87}$ e cinco años, poco más o menos, y su merced la mandó ${ }^{28}$ nonbre a quien quiere por su curador. El qual ${ }^{29}$ nonbró a Diego Avellán procurador e vecino de esta ${ }^{30}$ cibdad, presente, que acebtó el dicho cargo e juró en forma ${ }^{31}$ de derecho de lo usar bien, fiel e diligentemente ${ }^{32} \mathrm{e}$ hazer lo que debe y es obligado e dio ${ }^{33}$ por su fiador a Sebastián de las Peñas, vecino ${ }^{34} \mathrm{~d} e$ esta cibdad, presente, que acebtó la dicha fiança y ${ }^{65}$ los dos de mancomún renunciado las leyes de $1 a^{36}$ mancomunidad, como en ellas se contiene ${ }^{37} \ldots \ldots$.

(f. $3 v{ }^{1}$ lo que de suso tiene jurado e prometido, e si por ${ }^{2}$ culpa del dicho 
curador algún daño viniere al dicho menor, ${ }^{3}$ lo pagarán por sus personas e bienes, que para ello obli- ${ }^{4}$ garon e dieron poder a la justicia para que les apremien a ello como por sentencia pasada en $\operatorname{cosa}^{6}$ juzgada, sobre que renunciaron las leyes en su fabor ${ }^{7}$ y la ley general. $Y$ el dicho curador lo firmó ${ }^{8}$ de su nonbre. E a ruego del dicho fiador, firmó ${ }^{9}$ un testigo, porque dixo que no sabía escrivir, siendo ${ }^{10}$ presentes por testigos Francisco de Nabarrete, alguacil ${ }^{11}$ mayor, e Pedro Tomás, e Pedro Moreno, vecinos y estantes en esta ${ }^{12}$ cibdad. Diego Avellán, Pedro Moreno, Andrés de la ${ }^{13}$ Cadena, escrivano público.

14 E luego el dicho señor alcalde le discernió el dicho cargo ${ }^{15} \mathrm{y}$ le dio poder judicial para lo usar y exercer en forma ${ }^{16}$ de derecho. Testigos los dichos, y lo señaló de su señal Andrés ${ }^{17}$ de la Cadena, escrivano público.

${ }^{18} \mathrm{E}$ luego el dicho señor alcalde mayor le mandó tornar a leer ${ }^{19}$ su dicho e confisión, que tiene el dicho en esta causa, ${ }^{20}$ al susodicho, pues dize que es xristiano y se dize ${ }^{21}$ Juan. Del qual por que de nuebo por dezir, como dize ${ }^{22}$, que es xristiano e su merced le preguntó si es xristiano ${ }^{23}$ e dixo que es xristiano e que es de la Raguza, que cae ${ }^{24}$ de aquella parte de Venecia, y le mandó antes ${ }^{25}$ que se le tome su confisión debajo de juramento ${ }^{26}$ que se santigue e diga la dotrina xristiana. ${ }^{27} \mathrm{El}$ qual dixo el avemaría y el paternoster ${ }^{28}$ en latín y se enpeçó a santiguar, aunque ${ }^{29}$ no bien. E preguntado el creo y la salberregina ${ }^{30}$ dixo que lo savía en su usança e lengua aragu- ${ }^{31}$ zesa, que es de la Eslabonia, e no obo persona que ${ }^{32}$ que entendiese la dicha lengua. Preguntado que a donde ${ }^{33}$ es la Esslabonia, dixo que de aquella parte ${ }^{34}$ de Venecia, como tiene dicho. Y el dicho señor ${ }^{35}$ alcalde le preguntó que cómo comiença la salbe regina ${ }^{36}$ e el credo, en su lengua e usança. Dixo que la ${ }^{37}$ salbe regina comiença: Dios te salbe madre de ${ }^{38} . \ldots \ldots \ldots \ldots \ldots \ldots$ y el credo comiença: Credo y señor (f. 4 r) ${ }^{1}$ Jesuxristo salbanos por tu misericordia. E que como $1{ }^{2}$ cautibaron chiquito no se aquerda de más. E luego, atento ${ }^{3}$ que dize que es xristiano e dixo el abemaría y el ${ }^{4}$ paternoster, y las demás oraciones no las ${ }^{5}$ supo declarar, y el dicho señor alcalde no las ${ }^{6}$ entendió como lo dize la dicha lengua, ni ${ }^{7}$ en esta ciudad ay persona que entienda la dicha ${ }^{8}$ lengua, pero que en sus palabras paresce ${ }^{9}$ xristiano, le mandó que jurase, e así juró en forma ${ }^{10}$ devida de derecho, so cargo del dicho juramento su merced ${ }^{11}$ le mandó leer su dicho que dixo ante Hernando de Bel${ }^{12}$ monte, alcalde de su merced, en su absencia, y el ${ }^{13}$ que agora a dicho en presencia del dicho señor alcalde mayor. ${ }^{14} \mathrm{E}$ así le fue leido e declarado por mí el ${ }^{15}$ dicdo escrivano. Presente el dicho Diego Avellán, ${ }^{16}$ procurador, el cual abiéndolos oydo y en- ${ }^{17}$ tendido los dichos suso-dichos, dixo que es verdad lo que ${ }^{18}$ en ellos tiene declarado y en ello se afir- ${ }^{19}$ mava e afirmó, ratificava e ratificó 20 y si es necesario lo dize e declara ${ }^{21}$ agora e de nuebo.

${ }^{22}$ Preguntado que Chuce, su amo, de dónde ${ }^{23}$ era, dixo que turco era de nación, e que estubo ${ }^{24}$ cinco años con Chuce, e que andava por la mar ${ }^{25}$ e iba a Bélez e a Tetuán y en biages con el ${ }^{20}$ dicho Chuce, su amo. Preguntado que a qué parte ${ }^{27}$ iba a residir y estar el dicho Chuce, su amo ${ }^{28}$, dixo que parava en Argel y en Tetuán y en Vélez ${ }^{29}$ e que no tenía casa, sino que era cosario e ${ }^{20}$ que el dicho navío de donde se salió este qonfesante ${ }^{31}$ era del dicho Chuce, su amo, y de Bequiertarco ${ }^{32}$ tanbién cosario.

${ }^{33}$ Preguntado que quanto a que servia al dicho Chuce ${ }^{34}$ desde que le servía, dixo que cinco años le sirvió, ${ }^{35}$ como tiene dicho, e al principio le sirbió de bogar ${ }^{36}$ al remo y de traer agua e levar, como ${ }^{37} \ldots \ldots \ldots \ldots \ldots \ldots \ldots$ puertos 
(f. 4v) ${ }^{1}$ de Berberia, e después servía de dar la menja ${ }^{2}$ que era dar de comer a la gente.

${ }^{1}$ Preguntado que quando chiquito de qué a servido en las ${ }^{4}$ dichas galeotas e a quién sirvió de bardaxa, dixo ${ }^{5}$ que así le ayude la Virgen Marla que nunca ${ }^{6}$ sirvió de bardaxa, porque su amo tenía dos gar- ${ }^{7}$ çones que hel uno hera de Gibraltar y el otro ${ }^{8}$ le dezían el español e no save más.

9 Preguntado que quando su amo le per- ${ }^{10}$ suadió que fuese moro, como lo dize en la ${ }^{11}$ dicha su confisión, de qué manera hizo cirimonia ${ }^{12}$ de moro, dixo que su amo le dezía cada día que se ${ }^{13}$ tornase moro y este qonfesante le dezia: ¡Señor, dexame ${ }^{14}$ agora, que yo me tornaré moro! $\mathrm{E}$ que esto lo dezia ${ }^{15}$ con la boca, pero que en el coraçón no tenía tal.

${ }^{16}$ Preguntado que por qué dezía que se tornaría moro, pues ${ }^{17}$ que dize que no lo queria ser, dixo que porque le ${ }^{18}$ daban mala e por asegurallo e ve- ${ }^{19}$ nir-se a tierra de xristianos.

20 Por ser buen xristiano, como lo es.

21 Preguntado qué señales le hizieron quando se tornó ${ }^{22}$ moro dixo que no se tornó moro, ni le hizieron ${ }^{23}$ ningunas señales de moro.

${ }^{24}$ Preguntado cómo se salió del dicho vagel que no ${ }^{25}$ lo pudiesen ver pues que iban con ellos ${ }^{26}$ mudéjares que dize en su confisión ${ }^{27}$, dixo que como hazía escurana e venían ${ }^{28}$ muy callando porque nadie no los ${ }^{29}$ sintiese, de miedo de don Juan, e se ${ }^{30}$ dexó el barril dentro, en unas cañas, cerca ${ }^{31}$ del pozo de Ocho Ali, se fue a la montaña.

32 Preguntado quantos moros iban en el bagel, dixo ${ }^{33}$ que treinta moros soldados e cin- ${ }^{34}$ quenta e quatro remeros con este qonfesante.

${ }^{35}$ Preguntado quando salió el dicho vagel con la ${ }^{36}$ dicha gente de la armada que está sobre (f. 5r) ${ }^{1}$ Orán por tomar lengua acá, e quien $\operatorname{los}^{2}$ enbió, dixo que no vienen de la dicha ramada.

${ }^{3}$ Preguntado si los moriscos que se en- ${ }^{4}$ barcaron en el dicho vagel si heran moços ${ }^{5} \mathrm{o}$ viejos, e de dónde heran, e como iban ${ }^{6}$ armados, dixo que los quatro dixeron ${ }^{7}$ que heran de Almería y el uno dixo ${ }^{8}$ que abía sido llebado de Málaga y esta- ${ }^{9}$ va señalado en los dos carrillos con ${ }^{10}$ unas señales como redondas $e$ que ${ }^{11}$ entraron sigund e como tiene dicho, armados ${ }^{12}$ vallestas e un arcabuz.

13 E luego el dicho señor alcalde mayor le mandó ${ }^{14}$ diga la verdad, si renegó, e quantos años fue ${ }^{15}$ vardaxa y de quien con apercibimiento que ${ }^{16}$ mandó traer a Andrés Araquesache. E por no ${ }^{17}$ aver borrico mandó traer una escalera para ello ${ }^{18}$, y le apercibió, estando presente el dicho Andrés ${ }^{19}$ de Araque, que diga la verdad, como la está mandado, ${ }^{20}$ donde no, lo mande poner a quistión de tor21 mento. $\mathrm{Y}$ el dicho Juan Nicolo dixo que tiene, ${ }^{22}$ dicha la verdad e no tiene que dezir otra ${ }^{23}$ cosa. E luego el dicho señor alcalde mayor le bol- ${ }^{24}$ vió a percibir que diga la verdad demás ${ }^{25}$ de lo que le está preguntado le preguntó ${ }^{26}$ que dónde iba el dicho vagel encaminado, ${ }^{27}$ e de donde salió. Dixo que salió de Tetuán e venía a robar. Preguntado ${ }^{28}$ que para qué se salió del dicho vagel, dixo ${ }^{29}$ que para venir a tierra de xristianos e ser ${ }^{30}$ xristiano, como lo es. Preguntado que las cartas ${ }^{31}$ que se le hallaron en su poder, que quien ${ }^{32} \ldots \ldots \ldots \ldots \ldots \ldots \ldots$

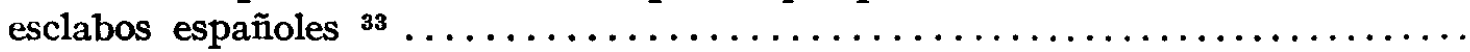
(f. $5 \mathrm{v})^{1}$ un portugués, porque, como él tenía boluntad ${ }^{2}$ de huirse e venirse a tierra de xristianos, les rogó ${ }^{3}$ que les hiziesen las dichas cartas para que se pa4 resciese la verdad y no lo estorbase nadie, ${ }^{5}$ e que las dichas cartas le escrivieron os dichos ${ }^{6}$ catibos xristianos a escondidas de los moros, ${ }^{7}$ porque si les vieran 
los moros escrivir las ${ }^{8}$ dichas cartas, los mataran a palos. ${ }^{9} \mathrm{Y}$ el dicho señor alcalde mayor mandó poner las ${ }^{10}$ dichas cartas originalmente en este proceso, ${ }^{11}$ porque provea justicia, su tenor de ${ }^{12}$ las quales hes el siguiente:

${ }^{13}$ Señores, este mancebo que lleba la presente ${ }^{14}$ nuestras mercedes lo faborezcan e ayuden en todo lo ${ }^{15}$ que fuere posible, porque es buen xristiano e ${ }^{16}$ gazia todo bien a xristianos, e aunque él dezía ${ }^{17}$ en la fusta que quería ser moro, no lo hes en verdad, ${ }^{18} \mathrm{ni}$ tiene hobras de ello. Por tanto vuestras mercedes, ${ }^{19}$ como tengo dicho, le ayuden, y esto pueden ${ }^{20}$ aver por verdad, porque aquí estamos 21 Bartolomé delBaeça y Graviel de Espinosa e Juan ${ }^{22}$ de Gibraltar para en fee e testimonio de verdad, ${ }^{13}$ porque quando otra cosa fuera de 10 24 escrito, lo pagaremos con nuestras personas. ${ }^{25} \mathrm{Y}$ no ay más que escrevir sino que le ${ }^{20}$ ayuden con toda la limosna que se ${ }^{28}$ pudiere, porque la meresce y porque es ${ }^{28}$ honbre forastero, para que pase su bida ${ }^{29}$ hasta que halle en qué trabaxar. Me ${ }^{30}$ encomiendo a vuestras mercedes, Bartolomé de Baeça ${ }^{31}$ y Grabiel de Espinosa y Juan de Alcántara ${ }^{32}$ Miguel de Limán. El sobrescrito de la dicha ${ }^{33}$ carta no se acertó a leer.

(f. 6r) ${ }^{1}$ seu amo querria fazer turquo elle na quis ${ }^{2}$ e lle dise que se fese na barqua para dar aviso ${ }^{3}$ a V. M. la doma es vro meu senser e native ${ }^{4}$ lugar de escrevir a V. M. uno degno ma ${ }^{5}$ isque bon ome.

${ }^{6}$ El sobrescrito de la dicha carta no se entendió ${ }^{7}$ ni obo quien declarase la dicha letra.

${ }^{8} \mathrm{Y}$ todavía el dicho señor alcalde mayor ${ }^{9}$ le requirió diga la verdad si salió por es- ${ }^{10}$ pía del dicho vagel, e a qué partes los enbiaron ${ }^{11}$ a espiar y en qué partes lo avian de esperar ${ }^{12}$ con la respuesta, que lo declare, donde no ${ }^{13}$, que todavía mandava e mandó traer recaudo ${ }^{14}$ para que el dicho Andrés de Araque esponga ${ }^{15}$ a quistión de tormento. El qual dixo ${ }^{16}$ que tiene dicho la verdad e no tiene más que decir.

17 Preguntado que como siendo esclabo trae calças ${ }^{18}$ e çapatos e que señal tiene en los piés ${ }^{19}$ de cuando se tornó moro. Y lo hizo descalçar ${ }^{20}$ e mirar para ello. El qual dixo que no tiene ${ }^{21}$ señal ninguna, e se le miró e no se le ${ }^{22}$ halló señal. E que de los que tomaron cerca ${ }^{23}$ de Málaga tomó los dichos çapatos ${ }^{24}$ porque tenía pensamiento de huirse e que ${ }^{25}$ las medias calças eran muchos días que las tiene.

${ }^{26} \mathrm{E}$ preguntándole todavía diga la ${ }^{27}$ verdad, dixo que la tiene dicho e que no tiene ${ }^{28}$ más que dezir.

${ }^{29}$ Preguntado si a estado en esta cibdad o en la ${ }^{30}$ ciudad de Vera otra vez, dixo que ninguna ${ }^{31}$ bez más de que quando cautibaron a Juan de Ortega ${ }^{32}$ vecino de esta cibdad, en la Carbonera, abrá más de ${ }^{33}$ un año, se halló este qonfesante en la galeota ${ }^{34} \ldots \ldots \ldots \ldots \ldots \ldots$. . . nía al remo.

(f. $6 \mathrm{v}$ ) ${ }^{1} \mathrm{E}$ luego visto que en esta cibdad no ay borrico de ${ }^{2}$ tormento no otros adereços para dalle ${ }^{3}$ tormento e que todabía dize que es $\mathrm{x} r$ ristiano ${ }^{4}$ el susodicho, el dicho señor alcalde mayor dixo que ${ }^{5}$ mandava e mandó que para que el Illustrísimo señor conde ${ }^{6}$ de Tendilla, capitán general del reino, 7 de Granada se informe del dicho honbre que ${ }^{8}$ se dize Juan de lo que sea servido e convenga ${ }^{9}$ sobre el cerco que dizen de Orán, e sobre ${ }^{10}$ otras cosas de que podrá ser informado ${ }^{11}$ del dicho Juan, e para que, en lo que toca a su ${ }^{12}$ anima, se provea lo que más convenga, ${ }^{13}$ mandava e mandó se lleve personalmente ${ }^{14}$ ante el dicho señor capitán general, o ante el ${ }^{15}$ muy illustre señor, don Luis Hurtado de ${ }^{16}$ Mendoça, su hijo, con el traslado de todos ${ }^{17}$ los avtos que están hasta agora hechos, 
${ }^{18}$ con las cartas originales que el dicho ${ }^{19}$ Juan mostró, quedando un traslado ${ }^{20} \mathrm{~d} e$ ello ante mi, el dicho escrivano. $\mathrm{E}$ así lo ${ }^{21}$ proveyó e mandó e firmó de su nombre, ${ }^{22}$ testigos Bartolomé Alonso Jurado e Juan de Ortega, ${ }^{23}$ vezinos de esta cibdad, e el licenciado Rodrigo de Herrera. ${ }^{24}$ Andrés de la Cadena, escrivano público.

${ }^{25}$ En la ciudad de Moxácar, veinte e nuebe días ${ }^{26}$ del mes de abril de mil e quinientos e sesenta ${ }^{27}$ e tres años. Ante el magnífico señor licenciado Rodrigo ${ }^{28}$. de Herrera, alcalde mayor de la dicha cibdad, paresció ${ }^{11}$ el dicho Juan Nicolao, preso, e Diego Avellán, ${ }^{30}$ procurador, e presentaron el escrito siguiente:

${ }^{31}$ Muy magnifico señor: Juan de Nicolao, natural ${ }^{32}$ de Eslabonia, que es de aquella parte de ${ }^{33}$ Venecia, digo que yo tengo necesidad para que ${ }^{34}$ conste a la real justicia de su magestad, a-doquiera ${ }^{35}$ que llegare e para ello de como yo me ${ }^{36}$ sali de la galeota de los turcos, henemigos (f. 7r.) ${ }^{1}$ de nuestra santa fee católica, estando la dicha ${ }^{2}$ galeota en do dizen la cala de San Pedro. Allí ${ }^{3}$ ciertos turcos y moriscos salieron con barriles ${ }^{4}$ a traer agua de la cala de San Pedro, e yo salí a hurto ${ }^{5} \mathrm{e}$ a bueltas de los turcos y moriscos que iban ${ }^{6}$ a traer agua para el nabío y, estando yo ${ }^{7}$ en tierra, yo me escabollé e me hize a la ${ }^{8}$ montaña huyendo, para me venir a algún ${ }^{9}$ pueblo de xristianos, e viniendo ${ }^{10}$ yo descubrí a un honbre que andaba en el ${ }^{11}$ monte, yendo yo a él para que me encami- ${ }^{12}$ nase a algún lugar de xrristianos, yo llegué ${ }^{13}$ a un que por su nonbre se dize Francisco ${ }^{14}$ de Almaraz, vecino de Moxácar, e junto que fui ${ }^{15}$ con él, hallé otro honbre vecino de Moxácar, ${ }^{18}$ que se dize Juan Ridao Saludador. E yo tengo ${ }^{17}$ nescesidad de que vuestra merced mande se tomen ${ }^{18}$ sus dichos d $e$ estos, y lo que dixere mandarseme ${ }^{19}$ en pública forma, para guarda de mi, Juan. ${ }^{20}$ Pidiolo por testimonio Juan de Nicolao.

$2^{11}$ E luego el dicho señor alcalde mayor le mando ${ }^{22}$ que presente los dichos testigos y es presto ${ }^{23}$ de los hesaminar e hazer justicia. Testigos ${ }^{24}$ Alonso Hernández, regidor de esta cibdad.

${ }^{25} \mathrm{E}$ luego, ante el dicho señor alcalde mayor, el dicho Juan de ${ }^{26}$ Nicolao presentó por testigo a Francisco de Al- ${ }^{27}$ maraz, vecino de esta cibdad, del que se tomó e ${ }^{28}$ recibió juramento en forma de derecho, e preguntado ${ }^{29}$ sigún de suso, dixo que lo que save es que el ${ }^{30}$ dia que este testigo truxo a esta cibdad al dicho ${ }^{31}$ honbre que se llama Juan Nicolao, a la una des- ${ }^{32}$ pués de medio día, poco más o menos, estando ${ }^{33} . . . \ldots \ldots \ldots \ldots$ e Juan Ridao el Saludador, en la ${ }^{34} \ldots \ldots \ldots \ldots \ldots \ldots \ldots$ del Garrobo (f. $7 \mathrm{v}$.) 1 asentados que el dicho Juan Ridao estava en su ${ }^{2}$ estancia, que es guarda alli, y este testigo venía del ${ }^{3}$ río Delias e abía parado a descansar ${ }^{4}$ vieron venir al dicho honbre, que venía de la vía ${ }^{5}$ de la cala de San Pedro. Y el dicho honbre ${ }^{6}$ se fue derecho a este testigo e al dicho Juan Ridao ${ }^{7}$ y se asentó allí con ellos, que paresció que venía ${ }^{8}$ cansado del camino, y le preguntaron ${ }^{9}$ que de donde venía. E dixo que aquella 10 noche antes se abía salido de los moros 11 de una galeota en la cala de San Pedro, que ${ }^{12}$ avian salido a hazer agua, e que se venía con los xristianos porque hera xristiano ${ }^{13}$ e abía estado catibo. E como el dicho honbre ${ }^{14}$ traía çapatos, e medias calças, e un capote, ${ }^{15}$ e una toca ceñida por el cuerpo, le dixo este 16 testigo que no traía arte de catibo, pues ${ }^{17}$ que venía tan bien tratado. $\mathrm{Y}$ el dicho honbre ${ }^{18}$ dixo que servía en la dicha galeota de dar ${ }^{19}$ de comer a la gente, e que por esto andaba bien ${ }^{20}$ tratado. $\mathrm{Y}$ le preguntaron que quanto avia ${ }^{21}$ que andava en las galeotas de moros.

${ }^{22} \mathrm{E}$ dixo que abía cinco años que estaba catibo. ${ }^{23} \mathrm{E}$ de esta manera 10 
truxo este testigo a esta cibdad ${ }^{24}$ y lo puso en la carcel de ella, e que esta es la verdad ${ }^{25}$ so cargo del juramento que fechotiene.

${ }^{26}$ Preguntado por las generales dixo que es de hedad ${ }^{27}$ este testigo de más de cincuenta años y que ${ }^{28}$ no le tocan las generales en cosa alguna. No lo firmó ${ }^{29}$ porque dixo que no sabia escrivir. Andrés de la Cadena, ${ }^{30}$ escrivano público.

${ }^{31} \mathrm{E}$ luego el dicho señor alcalde mayor mandó que se le entregue la ${ }^{32}$ dicha corona, e dineros, e anillos de plata, e toca ${ }^{33}$ e lo demás que le fue tomado al dicho Juan de Nicolao, ${ }^{34}$ que la dicha toca está en poder del dicho Hernando de Bel- ${ }^{35}$ monte............... esta cibdad pagándolos (f. 8r.) 1 hasta oy. $\mathrm{E}$ asi lo proveyó e mandó asentar por abtos e ${ }^{2}$ firmó de su nonbre, testigos Juanes de Unda, beneficiado e Pedro de $^{3}$ Unda, vecinos de esta cibdad el licenciado Rodrigo de Herrera, alcalde mayor. ${ }^{4}$ Andrés de la Cadena, escrivano.

${ }^{5} \mathrm{E}$ luego incontinente se le entregó al dicho Juan de Nicolao la ${ }^{6}$ dicha toca, e anillos, e corona de oro, y los dichos seis reales, ${ }^{7}$ y él lo recibió y d $e$ ellos pagó la costa e alimen- ${ }^{8}$ tos que a hecho, después que está preso. Testigos Juan de Bel${ }^{9}$ monte e Alonso Hernández Rodrigues e Andrés de Morales, vecinos ${ }^{10}$ de esta cibdad. E a su ruego firmó un testigo porque dixo que no ${ }^{11}$ savía escrivir. Andrés de Morales. Va entre renglones e enmendado ${ }^{12} \mathrm{o}$ diz iban y entrepretez no. Yo Andrés de la ${ }^{13}$ Cadena, escrivano de su magestad y escrivano del concejo y del ${ }^{14}$ número de la dicha ciudad de Moxácar, fui presente a todo ${ }^{15}$ lo que dicho es, que de mí se haze minción. Por ende ${ }^{16}$ lo escriví e saqué e fize mi signo atal 17 en testimonio de verdad. ${ }^{18}$ Andrés de la Cadena ${ }^{19}$, escrivano. ${ }^{20}$ Derechos de reales y saca, cinco ${ }^{21}$ reales. Pagolos Juan Nicolao.

${ }^{22}$ En la civdad de Vera, a primero día del mes de mayo ${ }^{23}$ de mill e quinientos e sesenta e tres años. Ante el magnífico señor ${ }^{24}$ licenciado Rodrigo de Herrera, alcalde mayor de esta ciudad, el dicho Juan Nicolao dixo ${ }^{25}$ que por que le conviene para su derecho e para que coste, como es cristiano, que ${ }^{26}$ se le tome su dicho a Gaspar Bázquez, vezino de esta ciudad, e se ponga atenjente ${ }^{27} \mathrm{~d} e$ esto pidió a su merced lo mande así probeer e pidió.............. testigos........ 28 ......... de Acosta e Diego de Canpos, vecinos de Granada.

(f8v). ${ }^{1}$ Del qual fue tomado e rescibido juramento en forma de derecho, e le fue preguntado ${ }^{2}$ lo susodicho. Dixo que lo que save de este caso que abía año e medio que los moros le cati- ${ }^{3}$ varon en la playa de la mar de ella y andando catibo al remo en una de qua- ${ }^{4}$ tro galeotas de moros, que eran de Arxel, que andava en compañia. 5 E este testigo vio, en otra galeota de moros, al dicho Juan Nicolao, que es el pro- ${ }^{6}$ pio a cuyo pedimiento se haze esto que le a sido y es mostrado. $\mathrm{Y}$ el suso dicho hera ${ }^{7}$ avido e tenido por cristiano, e lo llevaban herrado en la cadena al remo con ${ }^{8}$ los cristianos que estavan alli. Y que estando en Arxel asimismo vio e ${ }^{9}$ conosció al dicho Juan Nicolao, cristiano, andar con este testigo e con los de- 10 más cristianos que estavan alli, el qual hera catibo de un turco soldado ${ }^{11}$ que se llamava Chuzel, al qual save este testigo e vio que en le dicho tiempo ${ }^{12}$ que este testigo hestuvo catibo le conosció que era cristiano e así lo trata- ${ }^{13}$ van como tal cristiano, yendo aherrojado y en la cadena, e no entendió ${ }^{14}$ ni supo otra cosa en contrario. E que esta es la verdad so cargo ${ }^{15}$ del juramento que fecho tiene, e no lo firmó porque dixo que no savía escrivir e ${ }^{16}$ que es de edad de diez e ocho años, e que no le tocan las xenerales ${ }^{17}$ en cosa alguna, ni es andado ni sometido ni alguna cosa que.............. ${ }^{18} \ldots \ldots \ldots$ a la verdad. Va entre renglones e medio e do dize otra, ${ }^{19}$ e do dize vala, tachado una no vala. 
Esscribioo el ${ }^{20}$ dicho señor alcalde mayor. ${ }^{21}$ Ante mi, Juan de la Cadena. ${ }^{22}$ Escrivano público.

(f. 9r.) 1 Illustrísimo señor:

${ }^{2} J u a n$ de Nicolao, preso en esta carcel de vuestra señoría, digo que ${ }^{3}$ yo a cinco años que e sido captivo de un capitán turco que ${ }^{4}$ se llama Chuce y saliendo a hacer aguaje en el cabo ${ }^{5}$ de Gata, entre Moxácar y el mesmo cabo, una noche, a más de ${ }^{6}$ dos horas de la noche, con muncha escurana, me salí de- ${ }^{7}$ simulado entre los turcos y unos monfíes que avía recebido ${ }^{8}$ allí el mesmo capitán, que ivan a traer el agua y, así como es- ${ }^{9}$ tuvimos en tierra, me huí de entre los dichos .turcos y fui ${ }^{10}$ a parar a Mojácar con dos guardas que hallé en un es- ${ }^{11}$ tancia. Y llegados a Mojácar, la justicia de allí me embió ${ }^{12}$ ante vuestra señoría. Y porque yo estoy preso, sin culpa, soy ${ }^{13}$ cristiano, a vuestra señoría suplico, por servicio de Dios, me mande soltar, porque estoy aquí muriendo de hambre ${ }^{15}$, porque en ello hará vuestra señoría justicia y a mi gran ${ }^{16}$ bien y merced. Para lo qual etc. 17 Juan de Nicolao.

(f. 9v). ${ }^{1}$ En el allambra a diez de mayo de mill e quinientos e sesenta ${ }^{2} \mathrm{e}$ tras años. El illustrísimo señor qonde de Tendilla, capitán gentral de este $^{3}$ reino de Granada, aviendo visto este pleito mandó ${ }^{4}$ que se vea si el dicho Juan de Nicolao está renegado ${ }^{5} \mathrm{e}$ se traiga con los abtos.

${ }^{6}$ Este día fue sacado el dicho Juan de Nicolao y juró ${ }^{7}$ no estar renegado, de que doy fee, teśtigos............... e Juan de Ga- ${ }^{8} \ldots \ldots \ldots \ldots$. vecinos de la dicha alhambra.

- En el alhambra, a diez y siete de mayo de mill y quinientos y sesenta ${ }^{10}$ y tres años. Su señoría mandó soltar a el dicho Juan ${ }^{11}$ Nicolao y firmolo.

(f. ror.) 1 Illustrísimo Señor:

${ }^{2}$ Juan de Nicolao beso las manos de vuestra señoria y digo que yo me escapé ${ }^{3}$ de las galeras de los moros, e fui preso, e traido ante vuestra señoria ${ }^{4}$ y estado preso en la carcel de esta alhambra. E vuestra señoría me mandó soltar ${ }^{5}$ e como yo benga mal tratado e a manera de hombre de galera, me temo ${ }^{6}$ e recelo que yendo por algunas partes de este reino, para buscar ' mi vida e remediar, e me aprenderán. Suplico a vuestra señoría mande se me dé ${ }^{8}$ por el escrivano una fee de como e sido preso e suelto por mandado de vuestra señoria, ${ }^{9}$ sabiendo yo ser xristiano e no ser hombre de mal bibir, para ${ }^{11}$ lo cual etc. ${ }^{10}$ Juan de Nicolao.

11 En diez e nueve de mayo de MDLXIII años, que se le dé.

\section{VI}

Año I 563. Mojácar (Almería).

Juan Andrés napolitano escapado.

Archivo de la Alhambra.

${ }^{1}$ En la ciudad de Moxácar veinte e dos días del mes ${ }^{2}$ de septienbre de mill e quinientos y sesenta e tres años. ${ }^{3}$ Ante el señor Hernando de Belmonte, regidor de esta ciudad, alcalde ${ }^{4}$ en ella, por absencia del magnífico señor el licenciado Rodrigo de Herrera, ${ }^{5}$ alcalde mayor d $e$ esta ciudad y su juridición y en presencia ${ }^{6}$ de mí, Andrés de la Cadena, escrivano público y del consejo, ${ }^{7}$ de esta ciudad, pareció Juan Ximénez, guarda en la estancia ${ }^{8}$ de la Guarda Vieja d $e$ esta ciudad, e vecino de ella, y esibió e ${ }^{9}$ traxo a un mancebo en ábito de turco, e un ${ }^{10}$ menchón 
de cavellos en la caveça, y lo demás de la ${ }^{11}$ caveça rapado, sin barba, el qual truxo atadas ${ }^{12}$ las manos, al qual dixo que tomó en la ranbla ${ }^{13}$ de las tueras, cerca de la dicha Guarda Vieja. Que venía solo ${ }^{14}$, la marina adelante y costa $\mathrm{d} e$ esta cibdad, descalço ${ }^{15}$. Pidió al dicho señor alcalde se lo adjudique, por ser suyo, ${ }^{16}$ pues él lo tomó solo. E pidió justicia ${ }^{17}$ e juró que lo susodicho es cierto e verdadero e ${ }^{18}$ sin malicia.

${ }^{19} \mathrm{E}$ luego el dicho señor alcalde dixo que lo oyó e que hará justicia. ${ }^{20}$ E luego el dicho señor alcalde, en presencia de mí, el dicho escrivano ${ }^{21}$ preguntó al dicho mancebo que venía en ábito ${ }^{22}$ de turco y le hizo las preguntas siguientes:

${ }^{23}$ Preguntado que cómo se llama, dixo que Juan Andrés ${ }^{24}$ se 11 ama y en turquesco le llamavan Alí.

${ }^{25}$ Preguntado de qué nación es, dixo que na- ${ }^{26}$ politano y nació dentro, en Nápoles.

${ }^{27}$ Preguntado si oy dicho día lo tomó e traxo atado ${ }^{28}$ a esta cibad la guarda de la Guarda Vieja, dixo que este ${ }^{29}$ que declara venia a la marina adelante de esta cibdad ${ }^{30}$ y salió a él la dicha guarda e le ató.

(f. Iv.) ${ }^{1}$ Preguntado si es moro o xristiano este que ${ }^{2}$ declara dixo que xristiano hes.

${ }^{3}$ Preguntado si sabe la dotrina y oraciones xristianas, ${ }^{4}$ dixo que save el panoster y el avemaría ${ }^{5}$ e que no sabe otras oraciones y asi lo dixo ${ }^{6}$ rezando el paternoster y el abemaría.

${ }^{7} \mathrm{Y}$ el dicho señor alcalde atento que el dicho honbre dize ${ }^{8}$ ser xristiano, e que habla claro castellano, del qual ${ }^{9}$ tomó e recibió juramento, en forma debida de derecho, ${ }^{10}$ y le preguntó lo siguiente:

${ }^{11}$ Preguntado de dónde venía quando lo prendió ${ }^{12}$ la dicha guarda, dixo que de la Mesa de Roldán y de la ${ }^{13}$ Carbonera, de los navíos de moros, de seis galeotas ${ }^{14}$ de moros, que están en la dicha Mesa de Roldán y que ${ }^{15}$ se salió ayer tarde con dos oras de sol, de las dichas ${ }^{16}$ galeotas, solo, a nadar, y se escapó por una ${ }^{17}$ ranbla adelante, como vio como lo veía nadie. ${ }^{18} \mathrm{E}$ toda la noche a andado por la costa ${ }^{19}$ adelante, para venirse a esta ciudad huyendo ${ }^{20}$ de los moros, para ser xristiano, porque es xristiano.

21 Pr guntado que tanto a que está este que declara en poder ${ }^{22}$ de moros, dixo que abrá tres años que lo tomaron, ${ }^{23}$ yendo de Nápoles cargados de vino en una ${ }^{24}$ saetía, lo cautivaron dos galeotas a este qonfesante ${ }^{25} \mathrm{e}$ a otros tres, y lo llebaron Argel, e a salido ${ }^{26}$ dos vezes en viage con esta.

${ }^{27}$ Preguntado de qué parte de Berbería vienen las dichas ${ }^{28}$ seis galeotas, dixo que de Argel salieron e ${ }^{29}$ fueron a Bélez de la Gromera, e Viene en las ${ }^{30}$ dichas galeotas el alcaide de Vélez e que salieron ${ }^{21}$ de Vélez abrá ocho días e fueron la playa de la mar de esta cibdad, ${ }^{33}$ de donde se llebaron cinco varcas de pescar, ${ }^{34} \ldots \ldots \ldots \ldots \ldots$ la dicha Mesa de Roldán e alli ${ }^{35}$. ............

(f. 2r.) ${ }^{1}$ Preguntado si salió este confesante con los moros ${ }^{2}$ a saltear e hazer daño a los xristianos y a llebarse ${ }^{3}$ las dichas varcas, dixo que nunca a salido a tierra hasta agora que se salió.

${ }^{5}$ Preguntado que pues dize que es xristiano que como $10^{6}$ dexaban los moros andar suelto por las ga- ${ }^{7}$ leotas y en ábito de moro. Dixo que como ${ }^{\circ}{ }^{8}$ tomaron mochacho, se echaron con él y servía de ${ }^{9}$ bardaxa e garçon, e que se echaba con él Nabi, ${ }^{10}$ su amo. Y este confesante hera su garçón e ${ }^{11}$ por esto lo lleban suelto. $\mathrm{E}$ que sienpre ${ }^{12}$ a tenido miedo este qonfesante de los moros e por esto ${ }^{13}$ no se a huido hasta agora que tubo logar. 
14 Preguntado si este qonfesante renegó de nuestra santa fee ${ }^{15}$ católica y se tornó moro, dixo que nunca ${ }^{16}$ este qonfesante renegó de nuestra santa fee católica, ${ }^{17}$ ni se tornó moro, aunque los moros se $l^{18}$ rogaron a este qonfesante, no lo quiso ser, porque es xristiano.

${ }^{19}$ Preguntado por qué razón se llamava a este qonfesante aquel ${ }^{20}$ nonbre de moro Alí, dixo que los moros le ${ }^{11}$ pusuieron aquel nonbre y lo llamaban assí, ${ }^{22}$ por no llamarle nonbre de xristiano.

${ }^{23} \mathrm{E}$ que así hazen a los mochachos e garçones ${ }^{24}$ como este confesante.

${ }^{25}$ Preguntado si los dichos moros lo cortaron a este qonfesante ${ }^{26}$ el capillo del mienbro, como moro, dixo que no ${ }^{27}$ y el dicho señor alcalde lo miró e hizo mirar ${ }^{28}$ y no se halló cortado.

${ }^{29}$ Preguntado para qué traía este qonfesante el menchón de ca- ${ }^{30}$ vellos largos en la caveça, dixo que todos ${ }^{31} \ldots \ldots \ldots \ldots \ldots \ldots$ bardaxas llevan aquello así.

(f. 2v.) ${ }^{1}$ daño y si traen intento de llebarse algún ${ }^{2}$ pueblo de xristianos. Dixo que intento traen de hacer ${ }^{3}$ daño en esta costa y en la costa de Almeria $e^{4}$ tienen pensamiento de dar en un casar de la costa ${ }^{5}$ de Almeria, donde an hecho una torre nueba. ${ }^{6} \mathrm{E}$ que abrá quatro días que en le cabo Gata ${ }^{7}$ saltaron en tierra tres mudexares que ${ }^{8}$ venían en las dichas galeotas de Argel, ${ }^{9}$ que salieron a tomar lengua, y los tres ${ }^{10}$ mudexares y los dos moriscos se fueron ${ }^{11}$ a ebarcar a la Mesa de Roldán. E ante-12 de ayer, lunes, tornaron a saltar en tierra ${ }^{13}$ los cinco mudexares, a tomar lengua y espiar ${ }^{14}$ la tierra, e andar en tierra. $Y$ las galeotas ${ }^{15}$ los están esperando, para que buelba con lengua ${ }^{16}$ a enbarcarse a la Mesa.

${ }^{17}$ Preguntado si tiene padre e madre, e dónde ${ }^{18}$ e cómo se llaman, dixo que su padre era ${ }^{10}$ calabriese, y su madre napoletana, y su padre ${ }^{20}$ se dezia Nardu, vecino de Nápoles, y su madre se dezía ${ }^{21}$ Luca Antonia, e que murieron en Nápoles ${ }^{22}$ de una pestilencia, siendo pequeño este qonfesante. ${ }^{23}$ Que su padre murió en la carcel de Nápoles ${ }^{24}$ en un tormento, por muerte de un honbre, ${ }^{25}$ e que no se acuerda de ellos más de que un tío ${ }^{26} \mathrm{~d} e$ este qonfesante que se dize Marco de Riza, le dezía de ${ }^{27}$ su padre e madre de este qonfesante que es vecino de ${ }^{28}$ Nápoles y es escrivano. E que esta es la verdad, ${ }^{29}$ so cargo de juramento que fecho tiene, no lo firmó por-que dixo que no sabía escrivir, firmolo el ${ }^{31}$ dicho señor alcalde de su nonbre y asimismo ${ }^{32}$ la firmó Alonso Herreros regidor de esta cibdad, que se halló ${ }^{33}$ presente a lo susodicho, Hernando de Belmonte ${ }^{34}$ Alonso Herreros, Andrés de la Cadena, escrivano público.

${ }^{35} \mathrm{E}$ luego el dicho señor alcalde dixo que mandaba ${ }^{36}$ y mandó a Francisco de Nabarrete, alguazil ${ }^{37}$ mayor e alcaide de la carcel $\mathrm{d} e$ esta cibdad ${ }^{38}$............

(f. 3r.) ${ }^{1}$ dicho honbre que se llama Juan Andrés de manera que no ${ }^{2}$ se vaya y absente, so pena que sea a su culpa $\mathrm{e}^{3}$ cargo. $\mathrm{Y}$ lo firmó de su nonbre, testigos Alonso Hernández ${ }^{4}$ regidor a vecino de esta cibdad, Hernando de Belmonte, Andrés de la $^{5}$ Cadena, escrivano público.

${ }^{6} \mathrm{E}$ luego el dicho escrivano notificó el dicho abto de suso ${ }^{7}$ al dicho Francisco de Nabarrete, alguacil mayor e alcaide ${ }^{3}$ de la carcel de esta cibdad, el qual dixo que la carcel d $e$ esta ${ }^{9}$ ciudad hes ruin, que cada día se van los presos ${ }^{10} \mathrm{~d} e$ ella, e que este preso hes de calidad, e que el susodicho ${ }^{11}$ se podría ir de la carcel, que pide al dicho señor alcalde ${ }^{12}$ le mande poner guardas, e que si se fuere de la ${ }^{13}$ carcel, que no sea a su culpa, testigos los dichos.

14 El luego el dicho señor alcaide dixo que pues en esta ciudad ${ }^{15}$ ay carcel 
y grillos y cadena para tenellos ${ }^{16}$ que le manda........... al dicho alguacil e carcelero. ${ }^{17}$ Testigos los dichos, presente que le fue notificado, Hernando 18 de Belmonte. ${ }^{19}$ Luego ante el dicho señoralcalde y en presencia de mí ${ }^{20}$ el dicho escrivano, pareció Alonso Hernández, requeridor ${ }^{21}$ de esta cibdad, como familiar que dixo ser por $\operatorname{los}^{22}$ señores inquisidores de este reino de Granada. ${ }^{23}$ e dixo que pide y suplica a su merced que informe ${ }^{24}$ de lo que fuese cierto del dicho honbre, lo mande ${ }^{25}$ enbiar e remitir a los dichos señores inquisidores ${ }^{26} \mathrm{~d} e$ este reino de Granada, que están en la dicha cibdadi, ${ }^{27}$ de Granada, atento que el dicho honbre confiesa ${ }^{28}$ aver sido bardaxa e garçón de los moros ${ }^{29}$ e que se llamava Alí, nonbre de moros, e que ${ }^{30}$ xristianos nuebos de este reino de Granada an ${ }^{31}$ entrado y salido en los dichos nabios de moros, ${ }^{31}$ para que los dichos señores inquisidores ${ }^{32}$ provean lo que más conbenga al servicio de Dios ${ }^{33}$ nuestro señor. E de como lo pidió e requirió, lo pidióo ${ }^{34} \ldots \ldots \ldots \ldots \ldots$ y lo firmó de su nonbre. Testigos Francisco de................ de esta cibdad. Alonso........

\section{VII}

Año 155 r. Almería.

Confesión del negro Mazote.

Archivo de la Alhambra, L-I I 2-20.

(f. 3r) 1 En la cibdad de Almeria a veinte e tres dias del mes de henero de ${ }^{2}$ mill e quinientos e un años. El señor Diego de Gibaje, ${ }^{3}$ teniente de capitán de la gente de guerra d $e$ esta dicha cibdad por ${ }^{4}$ absencia del magnifico señor don Gerónimo de la Cueva, capitán de la dicha ${ }^{5}$ gente, dixo que por quanto en la confisión que le fue tomada ${ }^{6}$ a Maçot, negro turco que dizen ser, anda bariando, $\mathrm{e}$ para sa- ${ }^{2}$ berse la verdad, si es moro, o turco, o xristiano, o de qué parte es, lo mandó ${ }^{8}$ llamar a la carcel pública de esta dicha cibdad e allí lo mandó poner ${ }^{9}$ en el potro, para se le dar tormento, para que en él diga e ${ }^{10}$ declare la verdad de lo que pasa sobre lo suso dicho. $\mathrm{E}$ así llevado a la dicha ${ }^{11}$ carcel fue puesto en el dicho potro, e puestos los cordeles e garrotes ${ }^{12}$ en piés e braços. E lo que dixo e aclaró es lo siguiente.

${ }_{13}$ Luego el dicho señor Diego de Gibaje dixo que por que de presente ay nueva de $14 . . . \ldots \ldots \ldots$........ galeotas de turcos que están en el cabo de Gata, e para que aclare ${ }^{15} \ldots \ldots \ldots \ldots \ldots \ldots$ Maçote negro si huyó o de ellas, o de otras, $\mathrm{e}$ porque se sepa ${ }^{11}$ la verdad de todo ello porque así conviene al servicio de su magestad, le mandóo ${ }^{17}$ dar e le dió el tormento siguiente:

18 Luego le fue preguntado al dicho negro Maçote qué lengua sabe, para que ${ }^{19}$ en ella le pregunten e aclare la verdad. El qual dixo que lengua ciciliana ${ }^{20}$ e turquesca sabe.

21 Luego por lengua del señor capitán Pedro de Samaniego, se le preguntó ${ }^{22}$ la verdad con protestación que si algún braço o mienbro ${ }^{23}$ se le quebrare sea a su cargo.

${ }^{24}$ Luego le fue enpeçado a echar un jarro de agua ${ }^{25}$ echado parte de él, dixo que él es moro.

${ }^{26}$ Luego tornándoselo a echar parte del dicho jarro, tornó a dezir ${ }^{27}$ que es moro.

${ }^{28}$ Iuego le fue preguntado como se llama e dixo que Maçote. Preguntado en 
qué navios vino dixo que en ocho galeotas de ${ }^{30}$ turcos qu binieron al cabo de qata. ${ }^{31}$ Preguntado como se llama el capitán dixo que Mahomet e que ${ }^{32}$ vinieron de los Gelbes.

(f. 3v.) 1 Preguntado que a donde se retajó, dixo que en Trípolis siendo de hedad ${ }^{2} \ldots \ldots \ldots \ldots \ldots \ldots$ años.

${ }^{3}$ Preguntado que a donde le bavtizaron, dixo que en Mesina, siendo ${ }^{4}$ que lo hurtó un moro e lo traxo a la mesma Mesina e que ${ }^{5} . . . \ldots \ldots$ allí lo vendieron. Preguntado quando lo vendieron que ${ }^{6}$ hedad tenia, dixo que de ocho años hera, poco más o menos, entonces.

7 Preguntado si lo llevaron a la iglesia, dixo que sí e que alli ${ }^{8}$ lo batearon. Preguntado que por qué dixo en su dicho e confisión ${ }^{9}$ que se llamava Xristóval, dixo que porque un morisco se lo dixo en ${ }^{10}$ Tavernas que dixera que se llamava Xristófal.

11 E luego andando bacilando en su dicho en lo que le preguntaban, le fue 12 echado un jarro de agua e dixo que él dirá la verdad apre- ${ }^{13}$ tándole los cordeles con los garrotes.

${ }^{14}$ Preguntado como se llama el amo que dixo que teni en Sebilla, ${ }^{15}$ dixo que se llama don Antonio Mercadante de Sevilla.

18 Preguntado que si pasó en una nao por estas partes de la mar, ${ }^{17}$ dixo que sí y que podrá aver un año. Preguntado que si conoce ${ }^{18}$ a Aguado en Granada y a Escobar, vecinos de Granada, dixo que sí los conoce.

19 Preguntado si le dixo algún-en que lo dixera, o si los conoce, él dixo ${ }^{20}$ que él los conoce e que el dicho Aguado es un honbre baxo de cuerpo reheiz.

21 Preguntado que si los conoció en Granada dixo que sí porque podrá aver seis meses ${ }^{22}$ lo svido en Granauia, e que el dicho Escobar tiene un caballo algo blanco.

${ }^{23}$ Preguntado que con quien vino de Sevilla a Granada, dixo que ${ }^{34}$ bino solo. Preguntado donde se acogía en Granada, dixo que en casa de ${ }^{25}$ un xristiano nuebo que se llama Alonso Zaharo.

${ }^{26}$ Preguntado si es dentro, en Granada, o fuera, donde bibe el dich Alonso ${ }^{27}$ Zaharo, dixo que fuera de Granada una legua, que no sabe como se $11 \mathrm{a}-{ }^{28} \mathrm{ma}$ el lugar.

29 Preguntado como se llama el padre del dicho Alonso Zaharo, dixo que so Zaharo.

31 Preguntado que tanto a que partió de Granada, dixo que abrá tres semanas ${ }^{32}$ que en Granada se acogía en casa de una que se llama su marido ${ }^{33}$ Antonio que bibe en la plaça nueva.

(f. 4r.) 1 Luego porque andaba bariando en su dicho, en lo que le preguntan, le fue echado ${ }^{2}$ un xarro de agua.

3 Luego le fue echado otro jarro de agua.

4 Luego le fue echado otro jarro de agua.

5 Luego le fue preguntado diga la verdad, el qual dixo que es moro e ${ }^{6}$ vino de las ocho galeotas e como lo maltrataban, huyó ${ }^{7}$ de los navios.

8 Preguntado que por qué a dicho que hera de Sevilla, de don Antonio ${ }^{9}$ Mercadante de Sevilla, dixo que un morisco junto a Tavernas ${ }^{10}$ le dixo que dixera que hera esclavo del dicho don Antonio.

11 Preguntado con quien estubo en Tavernas, dixo que cerca de Tavernas 12 en el canpo, con dos moriscos.

13. Preguntado quantos días estubo con los dichos moriscos, dixo que ${ }^{14}$ quatro 
quatro dias. Preguntado que quando salió de las galeotas ${ }^{15}$ por donde se fue a Tavernas, dixo que por la sierra e por partes de la mar.

${ }^{16}$ Preguntado que qué sacó de las galeotas, bestido e qué armas ${ }^{17}$ dixo que una chamarra colorada e un arco, e un alfanje.

${ }^{18}$ Preguntado que qué pastores heran e como se llamavan, dixo que él ${ }^{19}$ los conocerá si los vee, e que guardaban ganado cabrío, ${ }^{20}$ que el uno tenia dos bueyes prietos.

21 E luego el dicho señor Diego de Gibaje lo mandó quitar del potro. E firmolo 22............. el capitán Pedro de Samaniego, e Juan de Aldana, regidor, e ${ }^{23}$ Díaz de Gibaje. Diego de Gibaje. ${ }^{24}$ Pasó ante mí Francisco López, escrivano público.

\section{VIII}

Año I 55r. Tabernas (Almería).

Declaraciones de un pastor sobre

el turco negro.

Archivo de la Alhambra, L-122-13.

(f. 5r.) ${ }^{1}$ En la villa de Tavernas, juridición de la muy noble, ${ }^{2}$ cibdad de Almería, domingo XXIIII de enero año ${ }^{3}$ MDLI años. El señor capitán Diego de Gibaja, tiniente ${ }^{4}$ y el señor don Gerónimo de la Cueva, capitán, ${ }^{5}$ de la dicha cibdad por virtud del poder que de su merced tiene ${ }^{6}$ vino a esta villa de Tavernas a declarar e averiguar ${ }^{7}$ donde estuvo un turco que se tomó en el río de Almería. ${ }^{8}$ Para la dicha averiguación de lo suso dicho el dicho ${ }^{9}$ señor capitán preguntó Alonso Chodon, vecino de Mondújar, ${ }^{10}$ pastor del Orxosí, al qual fue preguntado si conoscía ${ }^{11}$ el turco que le fue mostrado, negro, dixo que no le ${ }^{12}$ conoscía.

${ }^{13}$ Fuele preguntado si estuvo este turco negro ${ }^{14} \mathrm{en}$ su hato, quatro o cinco dias. Dixo que nunca le ${ }^{\mathbf{1 5}}$ vido, mas que le dixo Alonso, hijo del Modaguar de Gádor, ${ }^{16}$ pasto (sic) del dicho hato, que avie pasado por el hato e le ${ }^{17}$ avie tomado el capote e que luego como le tomó ${ }^{18}$ fue huyendo con él. Y que el dicho Alonso Modaguar le dixo ${ }^{19}$ que le dicho negro le avie llamado que entrase en la ${ }^{20}$ choça y que el dicho pastor dio gritos.

${ }^{21} \mathrm{E}$ fuele preguntado, si quando el dicho pastor ${ }^{22}$ dio gritos, si acudio él e vino a las bozes. ${ }^{23}$ Dixo que si que el e Martín el Modaguar, padre ${ }^{24}$ del dicho Alonso, pastor.

${ }^{25} \mathrm{E}$ fuele preguntado si quando los susodichos ${ }^{26}$ llegaron al hato a las bozes, si los susodichos ${ }^{27}$ vieron al dicho turco negro alli, e le vieron tomar ${ }^{28}$ el capote. Dixo que no, mas que les dixo el pastor ${ }^{29}$ que el dicho turco negro, con dos onbres con él, avien ${ }^{30}$ llegado al dicho hato e le avian tomado el ${ }^{31}$ ca-pote e dos bueyes.

${ }^{32} \mathrm{E}$ fuele preguntado que que armas traien $\operatorname{los}^{33}$ susodichos e que color de ropa traie el dicho turco ${ }^{34}$ negro e sus conpañeros. Dixo que no vido éste nad: ${ }^{35}$ sino su conpañero, otro pastor, que le oie dezir que se ${ }^{36}$ llama Alazeraque, y que no le sabe el nonbre.

(f. 5V.) 1 E fuele preguntado si le dixo su conpañero Alazeraque ${ }^{2}$ que ropa le avia visto el dicho turco. Dixo que le dixo ${ }^{3}$ que le avie visto una capa negra, vieja.

4 fuele preguntado si vido a los conpañeros del dicho ${ }^{5}$ turco negro, que 
armas e que ropas traían. Dixo que él ${ }^{6}$ vido a los dichos conpañeros del dicho turco que ivan ${ }^{7}$ por el camino de Xergalque llevavan el uno una ${ }^{8}$ capa azul y el otro un capote castellano ${ }^{9}$ con una espada.

10 Fuele preguntado que como sabie él que heran los susodichos conpañeros del dicho turco. Dixo que su conpa- 12 ñero Alonso el Mogaduar le dixo que estavan aguar- ${ }^{13}$ dando al dicho turco fuera del hato.

${ }^{14}$ Fuele preguntado que por qué huyó ayer del dicho ${ }^{15}$ capitán e de los que ivan con él, si avie hecho ${ }^{16}$ algún delito por donde tiene miedo e no se ${ }^{17}$ dexó prender. Dixo que pensó que heran turcos, como ${ }^{18}$ lo que avien robado el hato, e se fue huyendo por- ${ }^{19}$ que no le matasen, e que le asieron dos onbres.

${ }^{20}$ Fuele preguntado que después que le asieron los dichos ${ }^{21}$ dos onbres que por qué sacó un puñal del cenete (sic) e una ${ }^{22}$ çurrafa para dar a los dichos onbres, para se huir de ellos. ${ }^{23}$ Dixo que él no hechó mano él a la çurrafa, sino ${ }^{24}$ que el soldado se la sacó y que él hechó mano con el ${ }^{25}$ dicho soldado a la dicha çorrafa e que el puñal tenía ${ }^{26}$ un çurrón que traíe puesto.

27 Fuele preguntado que quando el dicho capitán llegó ${ }^{28}$ a él que los dichos pastores le dixo que estuviese quedo ${ }^{29}$ que hera el capitán, que dexase la çurrafa de la mano. ${ }^{30}$ Dixo que como se lo dixeron dexó la çurrafa.

31 Fuele preguntado que si el dicho turco negro sabe al- ${ }^{32}$ garavia o qué lengua habla. Que no sabe. Lo qual todo ${ }^{33}$ dicho es juró en forma de derecho Alonso Chodón que es toda ver- ${ }^{34} \mathrm{dad}$, e lo dixo por lengua de Alonso Xifra, intérpetre ${ }^{35}$ e lo firmó de su nonbre.

(f. 6r.) 1 Para más averiguación de lo susodicho, el dicho ca- ${ }^{2}$ pitán recebió juramento de Alonso Alazona, pastor vecino de Mondújar, pastor de Mexia, el qual que dirá verdad ${ }^{4}$ a todo lo que le preguntaren y él su-piere.

'Fuele preguntado si conosce al dicho turco negro. ${ }^{\circ}$ Dixo que no, mas que vido un onbre rebuelta una ${ }^{7}$ capa negra a la cabeça, con un palo en la mano ${ }^{8}$ que iva una ranbla abaxo.

- Fuele preguntado que quando vino la noche que qué le lo dixo Alonso el Modaguar, su conpañero. Dixo que avie ${ }^{11}$ visto un negro en el hato e que le avie llamado el 12 negro y que no quiso ir allá.

19 Fuele preguntado si le dixo Alonso el Modaguar si le ${ }^{14}$ avie hablado el negro o que queria o de donde hera. ${ }^{15}$ Dixo que no le dixo nada sino que el padre del dicho ${ }^{16}$ Alonso el Modaguar le dixo que avie venido al hato un negro ${ }^{17}$ que avie tomado el capote e que se avie huido su ${ }^{18}$ hijo $\mathrm{d} e$ él.

19 Fuele preguntado si avie visto Alonso Chabon el dicho ${ }^{20}$ negro e si estuvo quatro días comiendo e be ${ }^{21}$ viendo en el hato. Dixo que no le vido ni estuvo, mas ${ }^{22}$ le vido desde lexos, que estava en alto, e que ${ }^{23}$ no sabe otra cosa, que iva como coxo.

${ }^{24}$ Fuele preguntado que que fue la cabsa que Alonso Chabón no se ${ }^{25}$ dexó prender. Dixo que porque agora a un año le ${ }^{25}$ salieron en Alhama tres onbres y de entonces ${ }^{37}$ tiene miedo, y por eso no se dexó prender a los soldados. Dixo que no le vido el pelear sino quererse ${ }^{29}$ huir, y que el dicho capitán le ató por fuerça.

${ }^{30}$ Fuele preguntado si vido los conpañeros del dicho ${ }^{31}$ negro. Dixo que no más del dicho negro y que esto ${ }^{32}$ es lo que sabe por el juramento que hizo. Lo qual dixo por lengua de ${ }^{33}$ Alonso Xifra que lo declara todo lo susodicho e lo firmó de su ${ }^{34}$ nonbre.

35 (En árabe). 
${ }^{36}$ Ansi-mismo fue rescibido juramento de Martin el Modaguar ${ }^{37}$ el qual aviendo jurado en forma de derecho dixo que el dirá ${ }^{38}$ la verdad de lo que............

(f. 6v.) 1 Fuele preguntado si supo que el dicho negro estuvo ${ }^{2}$ en su hato o quien se lo dixo. Dixo que su hijo Alonso ${ }^{3}$ el Modaguar le dixo que un negro e otros dos ${ }^{4}$ con él le avian hurtado un capote e que los otros ${ }^{5}$ dos onbres estavan aparte de allí e que avia dado bozes ${ }^{6}$ cuando vido el dicho negro en el hato, e que a estas bozes ${ }^{7}$ vino él, que andava con el ganado, a ver qué era, e que quando ${ }^{8}$ llegó no vido negro ni vido a nadie, mas que le dixo ${ }^{9}$ su hijo que le avían hurtado un capote e los otros 10 dos onbres avien hurtado los dos bueyes e que el ${ }^{11}$ dichonegro dixo a su hijo: Veni acá a la choça, e que ${ }^{12}$ su hijo no quiso ir e ansí se fue el dicho negro.

${ }^{13}$ Preguntado que pues que ninguno de ellos no tenia ${ }^{14}$ culpa que por qué no se dexó atar Alonso Chođon. Dixo que es loco.

15 Preguntado que quando el dicho capitán llegó a el ${ }^{16}$ dicho Alonso Chodon que por qué no se dexó atar y que este ${ }^{17}$ le dixo: dexate atar que es capitán.

${ }^{18}$ Preguntado si quando estavan para que se atase ${ }^{19}$ si algún soldado dio una cuchillada ${ }^{20}$ y el cayó que andavan peleando. Dixo que no lo ${ }^{21}$ vido mas que andavan unos debaxo e otros ${ }^{22}$ arriba. Y que esta es la verdad por el juramento que hizo, lo qual dixo por lengua de Alonso Xifra que lo firmó de su nonbre.

24 Fuele preguntado si le dixo al dicho capitán que él darie ${ }^{25}$ sus hijos, que no los prendiese, que él los llevarie Almería. ${ }^{26}$ Dixo que es verdad. (firma en órano los prendiese, que él los llevaria Almería ${ }^{11}$. Dixo que es verdad. (firma en árabe Alonso Xifra)

27 Dicho día Alonso Oley e Miguel Modaguar vecino de Mondújar ${ }^{28}$ a dos de mancomún a boz de uno tomaren en fiado ${ }^{29} \mathrm{~A}$ lonso Chabón e Luis Alazeraque e Diego Alonso Almodaguar ${ }^{30} . \ldots \ldots \ldots \ldots$ todos quatro que los pondrá en la cibdad de Almería el ${ }^{31}$......... tes en todo el día e si no los pusieran pagaran de pena ${ }^{32}$......... cientos mil maravedis para la obra de la casa real de Granada e para ${ }^{33}$ ello se obligaron en forma de derecho e dieron poder a las justicias e re- ${ }^{34}$ nunciaron las leyes e la ley general............ an de poner en casa ${ }^{35}$ del dicho capitán Diego de Gibaja e que allí se los an de entregar.

\section{IX}

Año ${ }_{5} 6_{4}$. Almería.

Declaraciones de un cautivo

que asistió a la cabalgada de Nixar.

Archivo de la Alhambra, L-I $75-I_{1}$

1 En la cibdad de Almeria a veinte de henero año de mil $\mathrm{y}^{2}$ quinientos y sesenta y cuatro años. El muy magnífico señor Juan ${ }^{3}$ de Ponte, capitán de la jente de guerra de esta cibdad de ${ }^{4}$ Almería e juez de ella por el ilustrísimo señor conde de Ten- ${ }^{9}$ dilla, capitán general de este reino, dixo que es in- ${ }^{6}$ formado que en esta cibdad está un honbre que cuando ${ }^{7}$ el alcaide de Vélez llevó la cavalgada de Níxar y Tor- ${ }^{8}$ val, estava captivo en los ocho navíos e para saber ${ }^{9}$ lo que pasó sobre la allegada a la costa del cabo de Gata ${ }^{10}$ e donde desenbarcaron y donde se deseenbarcaron (sic) e ${ }^{11}$ todo lo que pasó, e dias que estuvieron en este partido 
12 los dichos navios, e para lo que más pasó, hizo parecer ${ }^{13}$ e traer ante sí al dicho honbre. El qual dixo llamarse Juan Lorenço, hixo de Maria Rodríguez Burda, muxer que ${ }^{15}$ fue de Juan Lorenço, su padre, vecino que dixo ser de la cib- ${ }^{16}$ dad de Xibraltar y de él su merced recibió juramento ${ }^{17}$ en forma devida de derecho, e aviendo jurado le pre- ${ }^{18}$ guntó qué sabe e lo que pasó sobre lo susodicho e que ${ }^{19}$ le declare todo lo que en el caso puede declarar e ${ }^{20}$ dar razón y el propósito que el alcaide de Vélez ${ }^{21}$ tenía al tienpo que le dio libertad, así de la cib- ${ }^{22}$ dad de Arxel, e de su persona e navíos, para salir ${ }^{23}$ a hazer daño en esta costa. e si tenía algunos a- ${ }^{24}$ visos d $e$ esta tierra. Dixo que lo que sabe e pasa ${ }^{25}$ es que este testigo fue captivo del alcalde ${ }^{26}$ de Vélez que se llama Yahi Arraéz y dos di- ${ }^{27}$ as pasados partieron de Arxel seis navios e fu- ${ }^{28}$ eron la buelta de Bélez, y estando en Bélez llegó ${ }^{29}$ un morisco que dezían que era de este reino ${ }^{30} \ldots \ldots \ldots \ldots \ldots$ $\ldots \ldots \ldots \ldots \ldots$ (f. Iv.) ${ }^{1}$ se dize Haçán e le dixo al dicho alcaide de Vélez ${ }^{2}$ que si quería venir por un casar que se quería ir ${ }^{3} \mathrm{~d} e$ este reino de Granada y el dicho alcaide dixo que ${ }^{4}$ sí haria y que en qué partido era. $\mathrm{Y}$ el dicho moro ${ }^{5}$ le dixo que en el cabo de Gata y así salió de Bélez ${ }^{6}$ con seis navíos y vino la buelta de el (sic) dicho Cabo de Gata ${ }^{7}$ y más acá de la Mesa de en el pozo que dizen ${ }^{8}$ Chavali tomó tierra y echó en tierra al dicho ${ }^{9}$ Haçán morisco y otros dos ermanos de $\operatorname{los}$ que primero ${ }^{10}$ se avían pasado de Níxar y salieron a la tierra y $^{11}$ otro dia por la mañana bolvieron a los dichos navios por- ${ }^{12}$ que salieron la tarde antes, dos horas antes que se pusiese ${ }^{13}$ el sol, y cuando bolvieron vinieron con ellos otros dos ${ }^{14}$ moriscos de la tierra, que el uno hera alto de cuerpo ${ }^{15}$ y enpeçava a canecer, e traía un sayo verde e un son- ${ }^{16}$ brero con tafetán bermexo, bien hecho, jentil honbre, ${ }^{17} \mathrm{y}$ el otro su conpañero era honbre de buena estatura ${ }^{18}$ y dixeron todos al dicho alcaide de Vélez que no era ${ }^{20}$ tienpo por entonces e"que no tiene memoria qué tienpo era, mas que le parece que abrá tres meses, poco ${ }^{22}$ más o menos. $\mathrm{E}$ dixeron que no era tienpo porque la ${ }^{23}$ costa no estava sigura e la jente estava avisada ${ }^{24}$ e no estava la jente para poderse ir, por lo dicho. E que ${ }^{25}$ estuvieron hablando otras muchas cosas entre ellos y ${ }^{26}$ que los dos moriscos que vinieron de la tierra se tor- ${ }^{27}$ naron a desenbarcar y los tres de los navíos se quedaron ${ }^{28}$ en ellos. $\mathbf{Y}$ el dicho alcaide se fue entonces la buelta ${ }^{29}$ de Cartajena y Alicante y en Isla Grosa ${ }^{30}$ se juntaron otros dos navios y antes que se juntasen ${ }^{31}$ sobre Cartajena tomaron dos ........... (f. 2 r.) ${ }^{1}$ con sus seis navios, $e$ después de juntos los ocho ${ }^{2}$ navios e dos naos, fueron la vuelta de Vélez y allí 3 dexaron las naos e bolvieron a esta costa e fueron ${ }^{4}$ la buelta de Vera, e tomaron cinco barcas e se 1 le- ${ }^{5}$ varon las cuatro e la una dexaron e se bolvieron ${ }^{6}$ al dicho puerto, más acá de la Mesa de Roldán, ${ }^{7}$ donde allegaron con siete galeotas e cuatro ${ }^{8}$ barcas porque la una galeota se avía quedado ${ }^{9}$ en la Sierra del Cabo de Gata, haziendo guardia, ${ }^{10}$ e llegados al dicho puerto se juntaron todas ocho ${ }^{11} \mathrm{y}$ alli echaron al dicho Haçán y dos conpañeros su- ${ }^{12}$ yos y vinieron a la tierra e tardaron u11a ${ }^{13}$ noche y otro día dixeron que tienpo era ${ }^{14}$ que echasen la jente en tierra, que la jente ${ }^{15}$ e el casar estava en orden para venir, que bien ${ }^{16}$ podían ir por ella. E preguntándoles el al- ${ }^{11}$ caide que si avía jente de guerra que les ${ }^{12}$ ofendiese, e los dichos moriscos dixeron que no, ${ }^{13}$ que bien podían desenbarcar porque no avía ${ }^{14}$ jente de guerra. $\mathrm{Y}$ así desenbarcaron en ${ }^{15}$ tierra, un poco más al poniente de la torre ${ }^{16}$ de los Alumbres, en una caleta en la sierra, ${ }^{12}$ el un serro alto $\mathrm{y}$ echaron en tierra ocho ${ }^{18}$ vanderas $\mathrm{y}$ hasta seiscientos honbres de guerra 19 bien armados de escopetas y arcos y vallestas que ${ }^{20}$ no dexaron en los navíos; más ocho o diez honbres ${ }^{21}$ y de allí abaxo de guardia sobre los capti- ${ }^{22}$ vos, que 
estavan muy aherrojados no se osara ${ }^{23}$ menear honbre y saltaron en tierra al atarde- ${ }^{14}$ cer..................... sa- (f. 2v.) 1 liese el sol y estuvieron en tierra hasta que anocheció ${ }^{2}$, sus vanderas tendidas, e un morabito predicándoles y en ${ }^{3}$ anocheciendo, enpeçaron a marchar la buelta de.tierra. ${ }^{3} \mathrm{Ya}$ pues estava escurecido y los navios vinieron los cuatro ${ }^{5}$ de ellos sobre los lances de los pescadores al Cabo de Gata $\mathrm{y}^{0}$ los otros cuatro se quedaron en la sierra, e porque en- ${ }^{7}$ tró mucho levante, forcejando éon el dicho levante se ${ }^{8}$ juntaron estas cuatro galeotas con las demás, más ${ }^{9}$ al poniente do se desenbarcaron y no aquel día, sino ${ }^{10}$ otro día en la tarde se juntaron con las cuatro ga- 11 leotas que avian recibido la jente que se avia ${ }^{19}$ desenbarcado, e como se juntarot1, cada navío tomó su ${ }^{13}$ jente de su navio e con otros capitanes les dixeron ${ }^{14}$ como avian topado jente de cavallo e jente de a pié, ${ }^{15}$ e que avian faltadoles cuatro turcos, tres no su- ${ }^{16}$ pieron $\mathrm{d} e$ ellos y el uno mataron y a éste llevaron ${ }^{17}$ muerto, que era guardián del dicho alcaide que ${ }^{18}$ era honbre de hecho, e que avian peleado con la dicha 19 jente de guerra, e que se avían buelto e dexado 11 la dicha jente, e que llevaron cuatro cristianos cap- ${ }^{29}$ tivos, y este testigo les vido e habló con ellos e dezían ${ }^{23}$ que eran soldados los tres y el uno era un viexo, ${ }^{24}$ alto de cuerpo, que se llamava Santa Cruz. Y este ${ }^{25}$ testigo e otros captivos, preguntándoles como les avían ${ }^{26}$ captivado, dixeron los dichos tres soldados que avían ${ }^{27}$ venido con algunos de cavallo y les avían echado para ${ }^{28}$ les poner en la escucha, e que el uno de sus ${ }^{29}$ conpañeros, estando en una mata, contava la jente, ${ }^{30}$ y se avia apartado un turco y el soldado que (f. $3^{3 r}$.) ${ }^{1}$ que (sic) se lo dezía dixo que avía echado a huir ${ }^{2}$ e lo alcançaron, e que luego tomaron a $\operatorname{los} \operatorname{dos}^{3}$ conpañeros, e que otro se avía huido porque eran cuatro, e que luego que vido los moros, avía dado a huir ${ }^{5}$ e que las armas se llevaron a la mar, e dezían ${ }^{6}$ que por tener buenos piés, se avían escapado, estando ${ }^{7}$ los navíos juntos, estuvieron aquel día y otro $\mathrm{y}^{8}$ echaron suertes e díxoles bien el libro para que ${ }^{9}$ echasen la jente en tierra e así fueron más al ${ }^{10}$ levante, que sería media legua, o algo menos, porque ${ }^{11}$ era cerca de la torre, en las calas, a la parte del ${ }^{12}$ levante, y en una cala todos juntos echaron toda 13 la jente en tierra, con media ora de sol e con sus 11 vanderas, dexando los navíos con la guardia, como an- ${ }^{15}$ tes los avían dexado. $\mathrm{Y}$ luego como desenbarcaron ${ }^{\mathbf{1 6}}$, hizieron viaxes por una rambla arriba, a la buelta ${ }^{17}$ el un cerro alto y estuvieron aquella noche ${ }^{18}$ hasta otro dia a medio día, que vinieron con la ${ }^{19}$ jente del casar e ganado e bestias y alli donde ${ }^{20}$ se desenbarcaron, se tornaron a enbarcar con la ${ }^{21}$ dicha cavalgada e jente del casar, e que todos los ${ }^{22}$ honbres que se fueron del dicho casar, llevavan ${ }^{23}$ vallestas, e los mancebos y todo, e ivan todos ar- ${ }^{24}$ mados y asi mataron alli mucho ganado para ${ }^{25}$ comer, e se refrescaron y enbarcaron siete azé- ${ }^{26}$ milas, muy buenas, las mejores que allí llevaron ${ }^{27}$, según se las señalaron los moriscos del casar ${ }^{28}$ al dicho alcaide, señalándole las mexores.

29 Preguntado que si algunos moriscos o mujeres ${ }^{30} \mathrm{e}$ muchachos ivan de mala gana o con volun- ${ }^{31}$ tad de pasarse, dixo que los honbres todos ivan de buena gana, con su vallestas, e las (f. $3 \mathrm{v}$.). ${ }^{1}$ muxeres e niños e mochachos, algunos ivan llorando ${ }^{2}$ e de mala gana, e que en los navíos después los vido ir con- ${ }^{3}$ tentos, porque el alcaide de Vélez les ofrecia buenas ${ }^{4}$ obras y así dende allí partieron su viaxe para la ${ }^{5}$ buelta de Vélez, otro día por la mañana.

Pregun- ${ }^{6}$ tado que si oyó dezir a los dichos turcos por qué ${ }^{7}$ no avian llevado el otro casar que quedó en la sierra, ${ }^{8}$ dixo que allí dezían que avían ido al casar más ${ }^{9}$ alto de la sierra, e que los moriscos no avían querido ${ }^{10}$ ir con ellos, antes 
se avian salido del casar huyendo ${ }^{11}$ una sierra arriba, e que entonces no captivó ningún ${ }^{12}$ cristiano, sino que todos eran moriscos.

${ }^{13} Y$ haziendo su viaxe otro dia antes de mediodía, pasa- ${ }^{14}$ ron por esta playa e tocaron en las Roquetas, y allí ${ }^{15}$ estuvieron todo el día con una vandera tendida ${ }^{16}$ en la capitana, e mataron el ganado que llevavan ${ }^{17}$ y salaron con la sal de las Roquetas y aquella noche ${ }^{18}$ se partieron la vueita de Vélez y esperaron todo el día, ${ }^{19}$ para si avía quien viniese a rescatar, porque ivan ${ }^{20}$ alli un Jimenes, vecino de esta cibdad, e la guarda e sol- 21 dados que avian captivado.

${ }^{22} \mathrm{Y}$ llegaron a Vélez con su cavalgada, y a cabo de quinze ${ }^{23}$ días, rescataron a este testigo por ciento e sesenta ducados. ${ }^{24} \mathrm{Y}$ cuando vino de Vélez supo y entendió del dicho alcaide ${ }^{25}$ de Vélez su amo, e de la jente de guerra turcos, que a- ${ }^{26}$ viand e bolber otra vez presto al cabo de Gata, por otro ${ }^{27}$ casar, e que pensavan que saldrian pasado el mes ${ }^{28}$ de henero en que estamos, a la luna de febrero, ${ }^{29}$ porque no esperaban sino dos navíos de Arxel que ${ }^{30}$ harla un renegado suyo y a cobrar unos dineros ${ }^{31}$ de unos portugueses, e que si a esta luna no salen (f. 4r.) ${ }^{1}$ lo estopvara que estavan unos moros en la ${ }^{2}$ sierra de los Alerzes que andavan por levantarse.

${ }^{3}$ Preguntado que si el dicho alcaide tiene algu- ${ }^{4}$ nos avisos del rei de Arjel' para se juntar ${ }^{5}$ con más navios de los que aquí tiene dicho, dixo que no lo sabe:

${ }^{6}$ Preguntado que hizieron de los moros que llevaron del ${ }^{7}$ casar e de la ropa e bestias e muxeres e niños, ${ }^{8}$ dixo que los mulos el alcaide los tomó los seis, ${ }^{9}$ y el uno se llevó un arráez de un navío de Arxel ${ }^{10}$ por la mar, e que a los moriscos, honbres e muxeres ${ }^{11}$ e niños llevava a cada uno diez ducados, y el que ${ }^{12}$ no los pagava, les echava al remo e que los que ${ }^{13}$ no pagavan, los tenía a la cadena en la forta- 14 leza y a los que se quexavan, les echava al remo, ${ }^{15}$ como dicho tiene $\mathrm{y}$ este testigo vido meter al remo ${ }^{16}$ cinco $\mathrm{d} e$ ellos y el uno le echaron por conpañero ${ }^{17}$ a este testigo en su vanco.

${ }^{18}$ Preguntado que si durante el tienpo e las vezes ${ }^{18}$ que allegaron e días que estuvieron en la ${ }^{20}$ sierra del cabo de Gata si vieron guardas o hi- ${ }^{21}$ zieron algunas ahumadas en tierra, pues ${ }^{22}$ estavan de día claro e descubiertos e públicos, ${ }^{23} \mathrm{e}$ las calas e puestos. Dixo que no vido guardas, ${ }^{24}$ ni ahumadas, de día ni de noche y que de día ${ }^{25}$ estavan descubiertos e desenbarcavan de día e ${ }^{26}$ de noche estavan surtos en las calas con sus lun- ${ }^{27}$ bres e lanternas en cruxía, sin ningún recelo ${ }^{28}$ ni miedo de nadie, como lo podían estar las ga- ${ }^{39}$ leras de España. $Y$ esto es la verdad por el jura- ${ }^{30}$ mento que hizo e no firmó porque dixo que ${ }^{31}$ no sabia firmar. El dicho testigo es un (f. 4v.) ${ }^{1}$ honbre mancebo que enpieça a barbar e dixo será ${ }^{2}$ de edad de veinte e dos años e dixo aver estado ${ }^{3}$ captivo dos años y medio del dicho alcaide e venia ${ }^{1}$ bien ataviado de capa e sayo negro e saragueles ${ }^{5}$ azules de buen paño, e çapatos e gorra, e dixo ser ${ }^{6}$ marinero en un barco de Jibraltar de ${ }^{7}$ un devdo suyo que vino a esta cibdad con el dicho su ${ }^{8}$ barco que está surto en esta playa. (Sigue una una salva de erratas.)

${ }^{11}$ Yo Juan de la Trinidad escrivano de ${ }^{12}$ su Magestad real y del número de Almería, presente fui ${ }^{13}$ con el dicho señor, Juan de Aponte, a la declaración que ${ }^{14}$ hizo el dicho testigo e fize sacar el dicho traslado ${ }^{15}$ del registro que quedó en mi poder firmado del dicho ${ }^{16}$ señor Juan de Aponte, e por ende fize aquí este mi signo, ${ }^{17}$ que es atal ${ }^{18}$ en testimonio de verdad. Juan de la Trinidad. 
Año ${ }_{5} 69$. Vélez de la Gomera.

Pedro Ponce de Cabrera pide ser rescatado.

Archivo de la Alhambra, L-6 $63_{1}$.

(f. 8r.) ${ }^{1}$ si por ventura vuestra merced me pudiese remediar los ciento entre seño- ${ }^{2}$ res lo allegará vuestra merced si ponen tantica diligencia y si por ventura vuestra merced ${ }^{3}$ lo a de determinar de hacer a de ser luego, porque este es prove y no $\mathrm{me}^{4}$ venda, y la limosna tardara quando mucho quince dias o veinte. Si ${ }^{5}$ vuestra merced a de poner remedio en esto y lo remediare,con que vuestra merced me lo envíe ${ }^{6}$ en dos meses, no me venderá éste. $\mathrm{Y}$ si por ventura se tardare más, no ${ }^{7}$ me los envie, porque me avrán llevado a Fez, que lo a jurado ansí mi amo, que una ${ }^{8}$ ora más de dos meses no me esperará más no digo más sino que por amor ${ }^{9}$ de Dios vuestra merced lo provea, si ser pudiere, pues que otros sin padre $\mathrm{y}$ sin madre ${ }^{10}$ an salido y salen cada día con limosnas.

${ }^{11}$ Señor, si por ventura vuestra merced allegare estos cien ducados, vuestra merced me los en- ${ }^{12}$ víe en ropa, porque me lo pide en ropa, por manera que vuestra merced a de tomar a un ${ }^{13}$ sastre y preguntalle quanto entrará en una ropa para un clérigo, una ves ${ }^{14}$ tida y otra encima, con sus mangas anbas y dos, y los que dijere sacar de grana, ${ }^{15}$ la mejor que se hallare, para dos ropas, y para otras dos negras, y para una como cha- ${ }^{16}$ marra afor(r)ada de paño amarillo, bueno, y encima leonado y lo que dijere un ${ }^{17}$ sastre, que cada ropa tendrá, sacallo y no cortallo. $Y$ todo esto sea buen paño ${ }^{18} \mathrm{y}$ de raçonabre precio, $\mathrm{y}$ más dos freladas que cuesten quatro escudos, y lien- ${ }^{19}$ ço, el mejor que se hallare y más çelgado, para quatro camisas, lo que vieren que entrara, ${ }^{20} \mathrm{y}$ más quince cobdos, dcho de raso y siete de tafetán, que sea todo bueno, y si vuestra merced ${ }^{21}$ lo conoertare de hacer, no me escriva ninguna carta hasta que me lo envien ${ }^{22}$ y si lo cnviare y sobrare dinero todo como estare me lo escriva en cuen -23 ta cada cosa eo que costare, para que se los dé yo a mi amo por cuenta los cien ducados. ${ }^{24} \mathrm{Y}$ si vuestra merced uviere de escrivir, escriva vuestra merced en el sobrescrito: «(H) nase de dar ${ }^{25}$ a Diego de Palma. Mercader de Ceuta, para que las dé a un cativo que se llama fulano", para ${ }^{26}$ que vengan ciertas. No tengo más que decir, sino que nuestro Señor me lleve a su ojos ${ }^{27} \mathrm{y}$ de mi Señora y de mis ermanas y de todas mis tías y a mi tío, el señor dotor que ${ }^{28}$ agora es tienpo que haga por mí. Fecha en Vález de la Gomera a viii de avril ${ }^{29}$ año de D.S.S.IX (sic) años.

${ }^{30}$ Su muy obediente hijo. Pedro Ponce de Cabrera.

\section{$\mathrm{XI}$}

Año I570. Guadix (Granada).

Don Juan de Austria autoriza a Damián Hris, cristiano nuevo, para que siga viviendo en

Granada, libremente con su familia.

Archivo de la Alhambra, I,-18-6.

1 Este es el traslado, bien y fielmente sacado, de una cédula y provisión, escripta en papel, firmada ${ }^{2}$ del serenisimo señor, Don Juan de Austria y refrendada de Juan de Soto, su secretario, su tenor del ${ }^{3}$ qual dize ansi: 
${ }^{4}$ Don Juan De Austria, etc.

${ }^{5}$ Por la presente, por justos respetos que a ello nos thueven, nos contentamos y es nuestra vo- ${ }^{6}$ luntad que Damián Hris, vezino de la ciudad de Granada, xristiano nuevo, se quede ${ }^{7}$ y pueda vivir y morar en ella libremente, con su cassa y familia, como hasta aquí ${ }^{9}$ lo a fecho, sin embargo de la orden que ultimamente avemos dado para que los xristianos ${ }^{10}$ nuevos naturales de este reino salgan de él, y de otra qualquiera que en a- ${ }^{11}$ delante diéremos, como no sea particularmente contraria a esta y en su derogación, ${ }^{12}$ declarando, como declaramos, que las demás no son ni se entienden contra ${ }^{10}{ }^{13}$ susodicho. Por tanto mandamos a qualesquier ministros del Rey, mi señor, ${ }^{14}$ a quien toca o puede tocar, que no apremien ni consientan que el dicho Damián ${ }^{15}$ Hris, sea apremiado a salir fuera de esta dicha ciudad, y si oviere salido, o estuviere ${ }^{16}$ recluso en alguna parte, lo hagan soltar, sin ninguna excusa ni dilación ${ }^{17}$ para el dicho efecto, sin ponerle agora, ni de aquí adelante, travo ni inpedimento ${ }^{18}$ en sus tratos ni granjerías como sean lícitos, antes les anparen y defienden ${ }^{19}$ como leal vasallo de su magestad, que ansí conviene a su Real servicio. ${ }^{20}$ De la qual mandamos dar la presente que es hecha en Guadix a cinco de ${ }^{21}$ novienbre de 1570 años. Don Juan. Por mandado del señor don Juan, Juan de Soto.

\section{XII}

Año 1570 . Granada.

Don Juan de Austria autoriza a Hernando el-Baizi

a seguir viviendo en Granada y a llevar armas.

Archivo de la Alhambra, L-18-6.

(f. 2r.) ${ }^{1}$ Traslado de la cédula que presentó Hernando Elbaizi.

2Don Juan de Austria:

${ }^{3}$ Por quanto por buena relación que tenemos de vos Hernando El Baizi, 4 vecino de esta cibdad y de los naturales de este reino, y de la lealtad y fideli- ${ }^{5}$ dad con que siempre aveis servido y por ser honbre pacifico y de buen bibir, ${ }^{5}$ emos tenido por bien que no obstante que por los vandos que se an hechado (sic) para salir ${ }^{6} \mathrm{~d} e$ este reino todos los xristianos nuevos de él, no se aya de entender ni entienda ${ }^{7}$ con vos los tales vandos! Por tanto os damos licencia para bibir en esta cibdad ${ }^{8}$ de Granada por el tiempo que no aya horden en contrario de su Magestad o mía en su nonbre ${ }^{9}$ y que los tales vandos que sean hechado de aquí adelante se hechen, no seais ${ }^{10}$ obligado por ello a salir de la dicha cibdad, vos ni vuestra muger ni hijos, e mando a ${ }^{11}$ todos e qualesquier justicias de qualquier grado, calidad o condición, que no sola- 12 mente os apremien, ni obliguen a hazer lo contrario, mas os den el fabor e ayu ${ }^{13}$ da que para vuestra seguridad ovieredes menester, en lo tocante a bibir en esta dicha cibdad. ${ }^{14}$ Asimismo mando que dentro de ella $o$ en otra qualquier que estuviéredes, e que consientan ${ }^{15}$ traer espada e puñal y más lança de camino e fuera en el canpo, sin que ${ }^{16}$ por ello podaís inqurrir en pena alguna, e no se haga ende al, porque ansí ${ }^{17}$ convenir y es nuestra voluntad. Fecha en Granada a XXIX de novienbre de I570. Don Juan. ${ }^{18}$ Por mandado del señor don Juan. Juan de Soto. 


\section{INDICE DE DOCUMENTOS}

I.-Cédula de rescate de Alonso de Quesada, cautivo en Argel. Año I553, Valladolid. Archivo de la Alhambra, L-6-63.1

II.-Cédula de rescate de Gonzalo de Aguilar, cautivo en Argel. Año I558, Valladolid. Archivo de la Alhambra, L-6-6 $63_{2}$.

III.-Cédula de rescate de Sebastián de Nájara, cautico en Argel en la jornada del Conde de Alcaudete. Torquemada (Palencia). Archivo de la Alhambra, I-6-63. Año 1559 .

IV.-Cédula de rescate de Iñigo Delgado, Alférez de la compañía de Hernán Pérez del Pulgar, en la jornada del Conde de Alcaudete. Archidona (Málaga). Archivo de la Alhambra, L-6-638. Año 1560.

V.-Cautivo escapado de una galeota de turcos. Mojácar (Almería). Archivo de la Alhambra, L-I 22-12. Año I 563 .

VI.-Declaraciones de Juan Andrés, napolitano, bardaxa escapado de una galeota de turcos. Mojácar (Almería). Archivo de la Alhambra, I,-122-14. Año 1563 .

VII.-Confesión del negro Mazote. Almería. Archivo de la Alhambra, L-I I 2-20. Año I55I.

VIII.-Declaraciones de un pastor sobre el negro Mazote. Tabernas (Almería), Archivo de la Alhambra, I-I22-13. Año 155 r.

IX.--Declaraciones de un cautivo que asistió a la cabalgada del alcaide de Vélez de la Gomera contra Níjar. Almeria. Archivo de la Alhambra, L-T $75-I_{5}$. Año I 564 .

X.--Pedro Ponce de Cabrera pide ser rescatado desde Vélez de la Gomera. Vélez de la Gomera. Archivo de la Alhambra, L-6-633. Año I 569.

XI.-Don Juan de Austria autoriza a Damián Hris, cristiano nuevo, para que siga viviendo en Granada. Año 1570 . Guadix (Granada), Archivo de la Alhambra, L-18-6.

XII.-Don Juan de Austria autoriza a Hernando el-Baizi a seguir viviendo en Granada y a llevar armas. Granada. Archivo de la Alhambra, L-18-6. Año I 570 .

\section{INDICE DE PALABRAS}

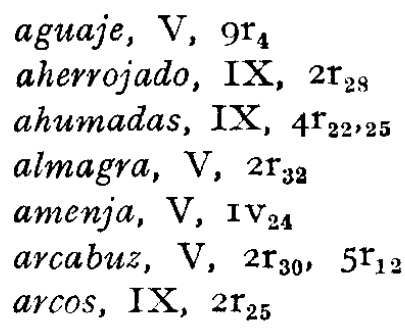

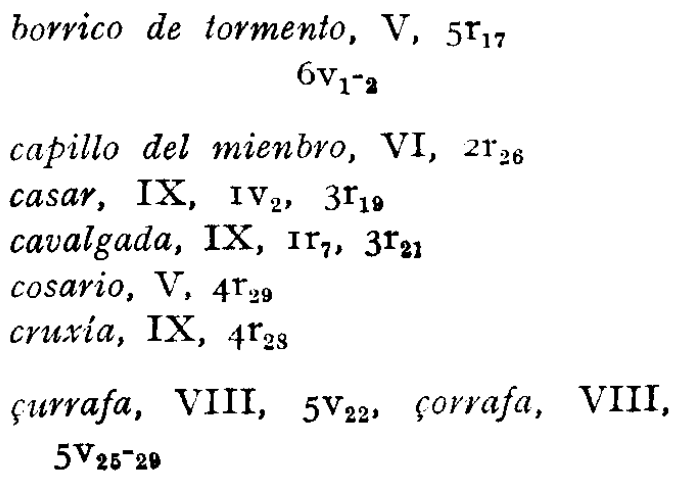


chamarra, $\mathrm{X}_{15^{-16}}$

escopeta, IX, $2 \mathrm{r}_{25}$

escurana, $\mathrm{V}, 4 \mathrm{~V}_{27} ; 9 \mathrm{r}_{6}$

galeota, IX, $2 \mathrm{v}_{8}$

garçón, VI, $2 \mathrm{r}_{9}, 3 \mathrm{r}_{28}$

habizes, $\mathrm{I}_{4} ; \mathrm{II}_{4} ; \mathrm{III}_{5} ; \mathrm{IV}_{3,5}$

lance de pescador, IX, $2 \mathrm{v}_{5}$

menja, $\mathrm{V}, 4 \mathrm{v}_{1}$

monfies, $\mathrm{V}, 9 \mathrm{r}_{\mathrm{q}}$ morabito, IX, $2 \mathrm{v}_{2}$

mudéjares, $\mathrm{V}, \mathrm{IV}_{10^{-}{ }_{17}} ; 4 \mathrm{~V}_{28} ; \mathrm{VI}, 2 \mathrm{~V}^{-}{ }^{-10}$

palangre, $\mathrm{V}, 2 \mathrm{r}_{7}$

raheiz, VII, $3 \mathbf{v}_{20}$

retajar, VII, $3 \mathrm{v}_{1}$

señales (en los piés al tornarse moro), $\mathrm{V}, 6 \mathrm{r}_{18^{-19}}$.

vallesta, $\mathrm{V}, 2 \mathrm{r}_{29} ; 5 \mathrm{r}_{12}$

* Los números hacen referencia a los documentos. 